\title{
Activation of Neurotensin Receptor 1 Facilitates Neuronal Excitability and Spatial Learning and Memory in the Entorhinal Cortex: Beneficial Actions in an Alzheimer's Disease Model
}

\author{
Zhaoyang Xiao, ${ }^{1 \star}$ Nicholas I. Cilz, ${ }^{1 \star}$ Lalitha Kurada, ${ }^{1 \star}$ Binqi Hu, ${ }^{1}$ Chuanxiu Yang, ${ }^{1}$ Etsuko Wada, ${ }^{2}$ Colin K. Combs, ${ }^{1}$ \\ James E. Porter, ${ }^{1}$ Florian Lesage, ${ }^{3}$ and Saobo Lei ${ }^{1}$ \\ ${ }^{1}$ Department of Basic Sciences, School of Medicine and Health Sciences, University of North Dakota, Grand Forks, North Dakota 58203, ${ }^{2}$ Department of \\ Degenerative Neurological Diseases, National Institute of Neuroscience, Tokyo, Japan, and ${ }^{3}$ Institut de Pharmacologie Moléculaire et Cellulaire, Centre \\ National de la Recherche Scientifique, and Université de Nice Sophia-Antipolis, Sophia-Antipolis, 06560 Valbonne, France
}

\begin{abstract}
Neurotensin (NT) is a tridecapeptide distributed in the CNS, including the entorhinal cortex (EC), a structure that is crucial for learning and memory and undergoes the earliest pathological alterations in Alzheimer's disease (AD). Whereas NT has been implicated in modulating cognition, the cellular and molecular mechanisms by which NT modifies cognitive processes and the potential therapeutic roles of NT in AD have not been determined. Here we examined the effects of NT on neuronal excitability and spatial learning in the EC, which expresses high density of NT receptors. Brief application of NT induced persistent increases in action potential firing frequency, which could last for at least $1 \mathrm{~h}$. NT-induced facilitation of neuronal excitability was mediated by downregulation of TREK- $2 \mathrm{~K}^{+}$channels $^{-}$ and required the functions of NTS1, phospholipase C, and protein kinase C. Microinjection of NT or NTS1 agonist, PD149163, into the EC increased spatial learning as assessed by the Barnes Maze Test. Activation of NTS1 receptors also induced persistent increases in action potential firing frequency and significantly improved the memory status in APP/PS1 mice, an animal model of AD. Our study identifies a cellular substrate underlying learning and memory and suggests that NTS1 agonists may exert beneficial actions in an animal model of AD.
\end{abstract}

Key words: glutamate; ion channel; memory; peptide; synapse; synaptic transmission

\section{Introduction}

Progressive deterioration of cognitive performance is a critical characteristic of Alzheimer's disease (AD), and improving cognitive function represents a major therapeutic approach for this disease. Current available therapies for $\mathrm{AD}$, including the cholinesterase inhibitors (Pepeu and Giovannini, 2009) and the partial NMDA receptor antagonist memantine (van Marum, 2008), provide only minimal benefit for a limited period to a subset of patients. Finding drugs that can improve memory is still a major method to relieve the symptoms of AD patients. Accumulating evidence demonstrates that neurotensin (NT), a tridecapeptide, and NT receptors are densely distributed in the entorhinal cortex

\footnotetext{
Received Jan. 29, 2014; revised March 31, 2014; accepted April 15, 2014.

Author contributions: J.E.P., F.L., and S.L. designed research; Z.X., N.I.C., L.K., B.H., and C.Y. performed research; E.W., C.K.C., J.E.P., and F.L. contributed unpublished reagents/analytic tools; Z.X., N.I.C., L.K., B.H., and C.Y. analyzed data; S.L. wrote the paper.

This work was supported by National Institute of Mental Health Grant MH082881. We thank Dr. Donghee Kim (Rosalind Franklin University of Medicine and Science, Chicago) for providing the mutant TREK-2 channel cDNA.

The authors declare no competing financial interests.

*Z.X., N.I.C., and L.K. contributed equally to this work.

Correspondence should be addressed to Dr. Saobo Lei, Department of Basic Sciences, School of Medicine and Health Sciences, University of North Dakota, Grand Forks, ND 58203. E-mail: saobo.lei@med.und.edu.

DOI:10.1523/JNEUROSCI.0408-14.2014

Copyright $\odot 2014$ the authors $\quad 0270-6474 / 14 / 347027-16 \$ 15.00 / 0$
}

(EC) (Wolf et al., 1994, 1995; Lahti et al., 1998; Hamid et al., 2002), a structure that is essential for learning and memory and undergoes the earliest pathological alteration in AD (Gómez-Isla et al., 1996). However, the physiological functions of NT in the EC, especially in learning and memory, and the therapeutic potential of NT receptor modulators for $\mathrm{AD}$ have not been determined.

NT-containing cell bodies and fibers have been detected in the EC and the structures that have inputs to the EC, such as olfactory tubercle, subiculum, amygdale, and claustrum (Chen et al., 1988; Atoji et al., 1995). NT interacts with three different types of NT receptors: NTS1, NTS2, and NTS3, of which NTS1 and NTS2 are G-protein-coupled (Vincent et al., 1999). NTS1 has higher affinity for NT and is blocked by the selective antagonist SR48692, whereas NTS2 has lower affinity for NT and is sensitive to levocabastine. NTS1 is functionally coupled to phospholipase C (PLC) pathway via Gq proteins (Hermans and Maloteaux, 1998; Vincent et al., 1999). The pharmacological and signaling properties of NTS2 are still controversial. In particular, it is unclear whether NT acts as an agonist, inverse agonist, or antagonist for this type of receptor. The functions of NTS2 are unclear, although it may be involved in NT-induced internalization of receptorligand complexes (St-Gelais et al., 2006). NTS3 is a single trans- 
membrane domain receptor and binds NT with high affinity (Vincent et al., 1999).

The EC is closely related to consolidation and recall of memories (Dolcos et al., 2005; Steffenach et al., 2005) and AD (Hyman et al., 1984; Kotzbauer et al., 2001). NT receptors are densely expressed in the EC, especially in the superficial layers (Wolf et al., 1994, 1995; Lahti et al., 1998; Hamid et al., 2002). However, the effects of NT in the EC, an indispensable structure in memory processing, and the potential uses of NT receptor modulators in $\mathrm{AD}$ therapy have not been determined. In the present study, we determined the roles of NT in facilitation of neuronal excitability and spatial memory and tested the effects of NT and PD149163, a small-molecule NTS1 agonist that can penetrate the blood-brain barrier, on improving spatial memory ability in an $\mathrm{AD}$ mouse model. Our research unraveled an unidentified cellular mechanism for memory and provides a potential approach for $\mathrm{AD}$ therapy.

\section{Materials and Methods}

Slice preparation. The ages of the animals used for electrophysiological recordings were postnatal 3-5 weeks for Sprague Dawley rats, individual knock-out (KO), and their corresponding wild-type (WT, C57BL/6J) mice. APP/PS1 mice ( $8-10$ months) were obtained from the The Jackson Laboratory: strain 005864 B6.Cg-Tg(APPswe,PSEN1dE9)85Dbo/J. Agematched C57BL/6J WT mice provided the control as described previously (Dhawan and Combs, 2012). Horizontal brain slices $(400 \mu \mathrm{m})$ were prepared as described previously (Wang et al., 2012, 2013; Zhang et al., 2014), except with the following modifications. After being deeply anesthetized with isoflurane, animals were decapitated and their brains were dissected out in ice-cold saline solution that contained the following (in mM): $130 \mathrm{~N}$-methyl-D-glucamine (NMDG)-Cl, $24 \mathrm{NaHCO}_{3}, 3.5 \mathrm{KCl}$, $1.25 \mathrm{NaH}_{2} \mathrm{PO}_{4}, 0.5 \mathrm{CaCl}_{2}, 5.0 \mathrm{MgCl}_{2}$, and 10 glucose, saturated with $95 \%$ $\mathrm{O}_{2}$ and $5 \% \mathrm{CO}_{2}(\mathrm{pH} 7.4$, adjusted with $\mathrm{HCl}$ ). Slices were then incubated in the above solution, except that NMDG-Cl was replaced with $\mathrm{NaCl}$ at $35^{\circ} \mathrm{C}$ for $1 \mathrm{~h}$ for recovery and then kept at room temperature $\left(\sim 24^{\circ} \mathrm{C}\right)$ until use. We found that these procedures yielded more viable slices from old animals.

Whole-cell recordings from entorhinal neurons. Whole-cell patch-clamp recordings using 4 Multiclamp 700B amplifiers (Molecular Devices) in current- or voltage-clamp mode were made from the principal neurons in the EC visually identified with infrared video microscopy (Olympus BX51WI) and differential interference contrast optics as described previously (Deng et al., 2006, 2010; Wang et al., 2011). Recordings were conducted at room temperature $\left(\sim 23^{\circ} \mathrm{C}\right)$. The recording electrodes were filled with the following (in $\mathrm{mm}$ ): 100 potassium gluconate, 0.6 EGTA, 5 $\mathrm{MgCl}_{2}, 8 \mathrm{NaCl}, 2 \mathrm{ATPNa}_{2}, 0.3 \mathrm{GTPNa}$, phosphocreatine 7, and 33 HEPES ( $\mathrm{pH} 7.3$ adjusted with $\mathrm{KOH}$ ). The extracellular solution comprised the following (in $\mathrm{mm}$ ): $130 \mathrm{NaCl}, 24 \mathrm{NaHCO}_{3}, 3.5 \mathrm{KCl}, 1.25$ $\mathrm{NaH}_{2} \mathrm{PO}_{4}, 2.5 \mathrm{CaCl}_{2}, 1.5 \mathrm{MgCl}_{2}$, and 10 glucose, saturated with $95 \% \mathrm{O}_{2}$ and $5 \% \mathrm{CO}_{2}, \mathrm{pH} 7.4$. Data were filtered at $2 \mathrm{kHz}$, digitized at $10 \mathrm{kHz}$, acquired on-line, and analyzed off-line using pCLAMP 9 or pCLAMP10 software (Molecular Devices).

Action potential (AP) firing was induced by injecting a positive current $(\sim 30-100 \mathrm{pA})$ to bring the resting membrane potential (RMP) to $\sim-50 \mathrm{mV}$ to induce a basal AP firing frequency of $0.2-1 \mathrm{~Hz}$ unless stated otherwise. Drugs were applied after the AP firing had been stable for 5-10 min. Frequency of APs was calculated by Mini Analysis 6.0.1 (Synaptosoft). Holding currents (HCs) at $-55 \mathrm{mV}$ were recorded in the extracellular solution containing TTX $(0.5 \mu \mathrm{M})$ every $3 \mathrm{~s}$ and then averaged per minute. We subtracted the average of the HCs recorded for the last minute before the application of NT from those recorded at different time points to zero the basal level of HCs for better comparison unless stated otherwise. I-V curves were constructed by using a ramp protocol from -140 to $0 \mathrm{mV}$ at a speed of $0.1 \mathrm{mV} / \mathrm{ms}$ in the external solution supplemented with (in $\mu \mathrm{M}$ ) $0.5 \mathrm{TTX}, 100 \mathrm{CdCl}_{2}, 10 \mathrm{DNQX}, 100 \mathrm{DL}-\mathrm{APV}$, 10 bicuculline, and 2 CGP55845 to block synaptic transmission and other voltage-gated ion channels. We compared the I-V curves recorded before and after the application of NT for 5-10 min.

EPSPs were recorded from layer II stellate neurons by placing a stimulation electrode in layer I to stimulate glutamatergic inputs in the extracellular solution containing bicuculline $(10 \mu \mathrm{M})$ and CGP55845 $(2 \mu \mathrm{M})$ to block GABAergic transmission. To prevent the propagation of epileptic activity in the presence of GABAergic inhibitors, a cut was made along the middle line of layer III (Wang et al., 2012, 2013). The intracellular solution was either the above $\mathrm{K}^{+}$-gluconate-containing intracellular solution or the intracellular solution in which $\mathrm{K}^{+}$was replaced by the same concentration of $\mathrm{Cs}^{+}$. The stimulation intensity was set to the level that produced $\sim 50 \%$ of the maximal EPSP amplitude. The stimulation frequency was set at $0.2 \mathrm{~Hz}$. The numbers of APs were counted within 150 $\mathrm{ms}$ after the stimulation artifact.

Transfection and electrophysiological recordings from transfected cells. Detailed procedures for transfection of HEK293 cells and electrophysiological recordings from the transfected cells were described previously (Deng et al., 2007, 2009; Xiao et al., 2009). Briefly, HEK293 cells were transfected with NTS1 alone, or together with WT TREK-2 channels or TREK-2 mutant. GFP was cotransfected for each experiment to identify the transfected cells. cDNA constructs coding for a human NT Type 1 receptor (GenBank accession number AY429106, subcloned into pCDNA3.1 vector) was obtained from the Missouri S\&T cDNA Resource Center (www.cdna.org). cDNA for the mutant TREK-2 channels was kindly provided by Dr. Donghee Kim (Rosalind Franklin University of Medicine and Science, Chicago) (Kang et al., 2006). cDNA constructs coding for TREK-2 (NM_021161, subcloned into the pCMV6-XL4 vector) were purchased from Origene. An empty pEGFP N-3 GFP fusion protein vector (GenBank accession number U57609) was purchased from Clontech. Transfected HEK293 cells were subsequently used for electrophysiological recordings $24-48 \mathrm{~h}$ after transfection. HCs at -55 $\mathrm{mV}$ were recorded from the HEK293 cells that showed fluorescence under a fluorescence microscope (Olympus 1X70) by whole-cell recordings. The extracellular solution contained (in $\mathrm{mm}$ ) $130 \mathrm{NaCl}, 3 \mathrm{KCl}, 2$ $\mathrm{MgCl}_{2}, 2 \mathrm{CaCl}_{2}, 1.25 \mathrm{NaH}_{2} \mathrm{PO}_{4}, 10$ HEPES, and 10 glucose ( $\mathrm{pH}$ adjusted to 7.4 using $\mathrm{NaOH}$ and $\mathrm{HCl}$ ). The above $\mathrm{K}^{+}$-gluconate internal solution was used for this experiment. A continuous gravity perfusion system (flow, $5-7 \mathrm{ml} / \mathrm{min}$ ) was used to change solutions.

Immunocytochemistry. The methods for immunocytochemistry were described previously (Deng and Lei, 2008; Deng et al., 2009; Xiao et al., 2009; Ramanathan et al., 2012). Briefly, horizontal sections (20 $\mu \mathrm{m})$ from rat brain were washed in $0.1 \mathrm{M}$ PBS and then treated with $0.3 \%$ hydrogen peroxide $\left(\mathrm{H}_{2} \mathrm{O}_{2}\right)$ for $10 \mathrm{~min}$ to quench endogenous peroxidase activity. After being rinsed in $0.1 \mathrm{M}$ PBS containing $1 \%$ Triton X-100 and $5 \%$ normal donkey serum for $30 \mathrm{~min}$, sections were incubated with the primary goat antibody to NTS1 (Santa Cruz Biotechnology, sc-7598) at a dilution of $1: 200$ at $4^{\circ} \mathrm{C}$ for $12 \mathrm{~h}$. Sections were incubated at room temperature initially with biotinylated donkey anti-goat IgG (Immunocruz Staining System, Santa Cruz Biotechnology) for $1 \mathrm{~h}$ and then with HRPstreptavidin complex (Immunocruz Staining System) for $1 \mathrm{~h}$. After each incubation, sections were washed three times for a total of $30 \mathrm{~min}$. Diaminobenzidine (Immunocruz Staining System) was used for a color reaction to detect the positive signals. Finally, sections were mounted on slides, dehydrated through an alcohol range, cleared in xylene, and covered with coverslips. We stained $\sim 10$ nonadjacent sections for each rat, and each staining was repeated by using 3 rats. For a control, NTS1 antibody was preabsorbed with the corresponding blocking peptide (Santa Cruz Biotechnology, sc-7598P) before being applied to the sections, and the other experimental procedures were the same as described above.

Immunoprecipitation and Western blot. Brain slices containing the EC were obtained from Sprague Dawley rats, WT (C57BL/6J) and TREK-2 KO mice $(n=6)$. For each animal, horizontal brain slices were cut initially, and the EC region was punched out from the slices under a microscope. The isolated brain region was treated with $0.25 \mu \mathrm{M}$ NT in the oxygenated extracellular solution for $5 \mathrm{~min}$ and then incubated in NTfree extracellular solution for varied times as described in Results. Tissue lysates from the EC were prepared as described previously (Deng et al., 2009; Xiao et al., 2009). The lysates were centrifuged at 14,000 rpm for 10 
min to remove the insoluble materials, and protein concentrations in the supernatant were determined (Bradford, 1976). Equivalent proteins were added to Eppendorf tubes, and TREK-2 protein from these lysates was immunoprecipitated using goat TREK-2 antibody ( $1 \mu \mathrm{g}$ antibody/mg protein; sc-11560, Santa Cruz Biotechnology) by overnight rocking at $4^{\circ} \mathrm{C}$. Protein was then added to the agarose beads $(40 \mu \mathrm{l}$ beads/IP, Protein A/G PLUS, Agarose, Santa Cruz Biotechnology) and rocked at room temperature for $2 \mathrm{~h}$. Beads were spun down and buffer was aspirated. Beads were then rinsed with cold RIPA buffer for $\sim 3-5$ times. Equal amount of sample buffer was added to the beads and then boiled for $5 \mathrm{~min}$ at $95^{\circ} \mathrm{C}$. The immunoprecipitates were resolved by SDS-PAGE and Western blotted with anti-phosphoserine antibody (Zymed Laboratories) (Glogauer et al., 1998; Nishimura et al., 1998; Yagi et al., 1999). Detailed methods for Western blot were described previously (Xiao et al., 2009; Ramanathan et al., 2012).

Barnes Maze Test. Detailed procedures for cannulation and microinjection to the EC were described previously (Deng et al., 2009). For the experiments with Sprague Dawley rats (male, 150-200 g), the Barnes Maze Test consists of a rotatable circular platform $(1.22 \mathrm{~m}$ in diameter and $1 \mathrm{~m}$ from the floor) with 18 holes $(9.5 \mathrm{~cm}$ in diameter) evenly spaced around the periphery. A removable box was placed underneath one of the holes for escape. The escape hole remained fixed in one location for each animal for all the trials. Visual cues were placed on the walls of the room and on two stands located $50 \mathrm{~cm}$ from the platform for spatial references. An auditory buzzer producing 80-100 dB was used as an aversive stimulus. On the first day of trials, each animal was placed on the platform without the escape box for $5 \mathrm{~min}$ allowing the animal to familiarize with the maze. The escape box was then placed, and the animal was placed into the escape box for $2 \mathrm{~min}$. At the beginning of each trial, a closed starting chamber was used to place the animal in the center of the platform. The auditory buzzer was then switched on. After $\sim 15 \mathrm{~s}$, the starting chamber was removed and the animal was allowed to explore the maze for $3 \mathrm{~min}$. Once the animal entered the escape box, the auditory aversive stimulus was stopped. If the animal failed to enter the escape box in $3 \mathrm{~min}$, it was guided to the escape box by the experimenter and the latency was counted as $180 \mathrm{~s}$. The animal was allowed to remain in the box for 1 min before the next trial. The platform and the escape box were wiped with $70 \%$ ethanol after each trial to eliminate the use of olfactory cues to locate the target hole. Each animal was subject to a session of 3 trials per day. The performance of the animal was recorded by Videomex-One monitor system (Columbus Instruments). For the experiments with mice, the experimental methods were generally the same as described above, except for the following differences. First, the Barnes Maze Test for mice consists of 40 holes. Second, the age of the mice was $\sim 2$ months (30-35 g) or 8-10 months for the APP/PS1 mice or age-matched control WT (C57BL/6J) mice, and the coordinates for the guide cannulae were anteroposterior $(-4 \mathrm{~mm})$, mediolateral $( \pm 3.4 \mathrm{~mm})$, and dorsoventral $(-4.8 \mathrm{~mm})$. Third, the training protocol was the same as that used for rats, except that we added another trial each day because our preliminary data suggested that more trials are required for the training of mice.

Data analysis. Data are presented as the mean \pm SEM. NT concentration-response curve was fit by the Hill equation as follows: $I=I_{\max }$ $\times\left\{1 /\left[1+\left(\mathrm{EC}_{50} /[\text { ligand }]\right)^{n}\right]\right\}$, where $I_{\max }$ is the maximum response, $\mathrm{EC}_{50}$ is the concentration of ligand producing a half-maximal response, and $n$ is the Hill coefficient. To differentiate the involvement of TASK-1 channels, we fit the net I-V curve induced by NT with the GoldmanHodgkin-Katz (GHK) current equation:

$$
I_{s}=P_{s} z_{s} \frac{E F^{2}}{R T} \frac{[S]_{i}-[S]_{o} \exp \left(-z_{s} F E / R T\right)}{1-\exp \left(-z_{s} F E / R T\right)}
$$

where $P_{s}$ is the permeability, $[S]_{\mathrm{i}}$ and $[S]_{\mathrm{o}}$ are the intracellular and extracellular concentrations, respectively, of potassium, $\mathrm{z}_{\mathrm{s}}$ is the valence, $F$ is Faraday's constant, $R$ is the gas constant, $E$ is the voltage, and $T$ is the absolute temperature. Paired or unpaired $t$ test was used to compare electrophysiological, quantified immunohistochemical, and Western blot data as appropriate. The data obtained from the Barnes Maze Test experiments were statistically analyzed by the repeated-measures ANOVA. $p$ values are reported throughout the text, and significance was set as $p<0.05 . N$ (number) in the text represents the cells examined, unless stated otherwise.

\section{Results}

NT induces persistent enhancement of neuronal excitability in the superficial layers of the EC via activation of NTS1

Autoradiographic studies have shown that NT-binding sites are detected in the EC, especially in layer II of the EC (Wolf et al., 1994, 1995; Lahti et al., 1998; Hamid et al., 2002). Accordingly, we examined the effects of NT on neuronal excitability by recording AP firing from the principal neurons in the medial EC of rats using whole-cell current-clamp configuration. The intracellular solution contained $\mathrm{K}^{+}$-gluconate, and the extracellular solution was supplemented with $10 \mu \mathrm{M}$ DNQX, $50 \mu \mathrm{M}$ DL-APV to block glutamatergic, and $10 \mu \mathrm{M}$ bicuculline and $2 \mu \mathrm{M}$ CGP55845 to block GABAergic transmission. In the superficial layers (layer II/III), stellate and pyramidal neurons are the two major neuronal types in layer II (Alonso and Klink, 1993; Canto et al., 2008), whereas pyramidal neurons are the principal neuronal type in layer III (Dickson et al., 1997). Application of NT $(0.25 \mu \mathrm{M})$ for 5 min increased the AP firing frequency by $8.93 \pm 1.94$-fold in stellate $\left(n=7, p=0.004\right.$; Fig. $\left.1 A_{1}, A_{2}\right)$ and $7.58 \pm 1.71$-fold in pyramidal $\left(n=8, p=0.003\right.$; Fig. $\left.1 B_{1}, B_{2}\right)$ neurons of layer II. The effect of NT lasted for at least $60 \mathrm{~min}$ after wash in NT-free extracellular solution in our whole-cell recording configuration. We also examined the effects of NT on AP firing frequency in the pyramidal neurons of layer III and layer V. Application of NT $(0.25 \mu \mathrm{M})$ induced a much smaller increase in AP firing frequency in the pyramidal neurons of layer III $(0.66 \pm 0.26$-fold increase, $n=8, p=0.04$; Fig. $1 C_{1}, C_{2}$ ) but failed to significantly enhance the AP firing frequency in layer $\mathrm{V}$ pyramidal neurons $(0.25 \pm$ 0.13 -fold increase, $n=9, p=0.09$; Fig. $1 D_{1}, D_{2}$ ). These results demonstrate that NT selectively facilitates neuronal excitability in the superficial layers (especially layer II) of the EC, consistent with previous and our immunohistological results (see below) showing that a high density of NT receptors exists in layer II of the EC (Wolf et al., 1994; Lahti et al., 1998; Hamid et al., 2002). Because stellate neurons are the principal neuronal type ( $69 \%)$ in layer II (Alonso and Klink, 1993), we recorded from the stellate neurons to further determine the underlying ionic and signaling mechanisms for the rest of the experiments. The $\mathrm{EC}_{50}$ of NT was measured to be $41 \mathrm{~nm}$ (effective concentration: 0.01-1 $\mu \mathrm{M}$; Fig. $1 E)$. Because the maximal effect of NT was observed at $0.25 \mu \mathrm{M}$, we used NT at this concentration for the rest of the experiments unless stated otherwise.

Whereas NT has been reported to modulate the release of glutamate (Yin et al., 2008; Kadiri et al., 2011) and GABA (O'Connor et al., 1992; Rakovska et al., 1998; Petkova-Kirova et al., 2008) in some brain regions, NT-induced persistent increase in AP firing frequency is unlikely to be mediated by glutamate or GABA because the extracellular solution contained blockers for glutamatergic and GABAergic receptors. Inclusion of MCPG (1 mM), a broad-spectrum metabotropic glutamate receptor (mGluR) blocker, in the extracellular solution failed to alter NTinduced facilitation of AP firing $(n=6, p=0.48$ vs NT alone; Fig. $1 F)$, excluding the involvement of mGluRs. NT has also been reported to modulate the releases of acetylcholine (Ach) (Lapchak et al., 1990, 1991; Rakovska et al., 1998; Petkova-Kirova et al., 2008) and dopamine (DA) (Faggin et al., 1990; Reyneke et al., 1992). Pretreatment of slices with and continuous bath application of atropine (10 $\mu \mathrm{M}$, muscarinic receptor blocker) and mecamylamine (100 $\mu \mathrm{M}$, nicotinic receptor blocker) failed to change NT-induced facilitation of AP firing frequency $(n=6$, 

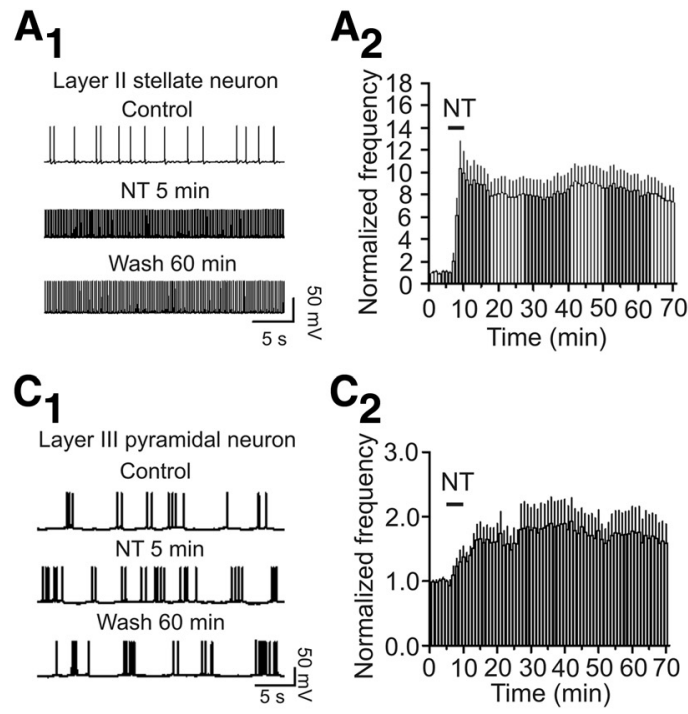
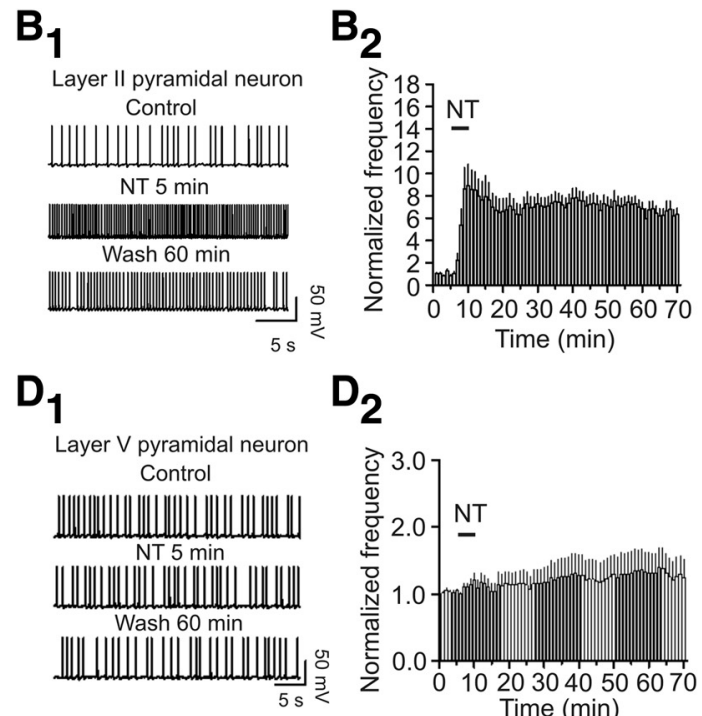

E

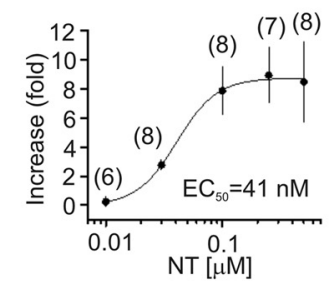

$\mathbf{F}$

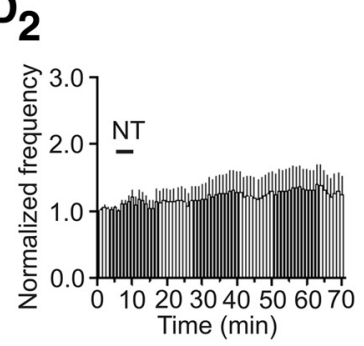

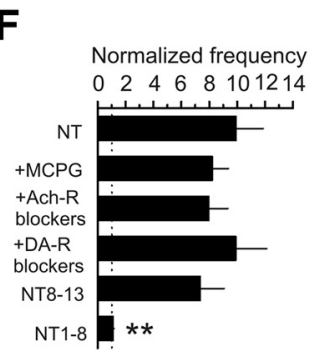

Figure 1. NT induces persistent increases in AP firing frequency in the EC. $A_{1}, A_{2}$, NT facilitated AP firing frequency in layer II stellate neurons. $A_{1}$, APs recorded from a stellate neuron in layer II before, during, and after the application of NT. $\boldsymbol{A}_{2}$, Pooled time course of NT-induced enhancement of AP firing frequency. $\boldsymbol{B}_{1}, \boldsymbol{B}_{2}, \mathrm{NT}$ enhanced AP firing frequency in layer II pyramidal neurons. The figures were assembled in the same fashion. $\boldsymbol{C}_{1}, \boldsymbol{C}_{2}, \mathrm{NT}$ elicited a lower level of increase in AP firing frequency in layer III pyramidal neurons. $\boldsymbol{D}_{1}, \boldsymbol{D}_{2}, \mathrm{NT}$ failed to alter AP firing frequency in layer $V$ pyramidal neurons. $E$, Concentration-response relationship of NT-induced enhancement of AP firing frequency recorded from layer II stellate neurons. Numbers in parentheses are the numbers of neurons recorded. $y$-axis represents the fold increase of AP firing frequency recorded at the fifth minute after the beginning of NT application at different concentrations. $F$, NT-induced facilitation of AP firing frequency was not affected by applications of blockers for mGluRs (MCPG), acetylcholine receptors (Ach-R, atropine, and mecamylamine), and dopamine receptors (DA-R, SCH23390, and sulpiride), but application of the active (NT8 -13), not the inactive (NT1-8), fragment of NT mimicked the effect of NT. ${ }^{* *} p<0.001$ versus NT alone.

$p=0.44$ vs NT alone; Fig. $1 F)$, suggesting that it is unlikely that NT facilitates neuronal excitability via releasing Ach. Furthermore, application of SCH23390 (10 $\mu \mathrm{M}, \mathrm{D}_{1}$-like receptor antagonist) and sulpiride (100 $\mu \mathrm{M}, \mathrm{D}_{2}$-like receptor antagonist) in the same fashion did not alter NT-induced enhancement of AP firing frequency $(n=5, p=0.99$ vs NT alone; Fig. $1 F)$. These results together indicate that it is unlikely that NT-induced facilitation of AP firing is mediated indirectly by modulating the release of Ach and DA. Finally, application of NT in the pure extracellular solution without any blockers for any receptors still enhanced the AP firing frequency to the same level ( $8.4 \pm 3.1$-fold increase, $n=6$, $p=0.04$; data not shown) supporting a physiological role for NT-induced facilitation of neuronal excitability in the EC. Bath application of the active NT fragment (NT8-13, $0.25 \mu \mathrm{M})$ increased the AP firing frequency to the same level as NT $(n=6$, $p=0.35$ vs NT alone; Fig. $1 F)$, whereas application of the inactive fragment (NT1-8, $0.25 \mu \mathrm{M}$ ) failed to increase AP firing frequency $(n=7, p=0.093$ vs baseline; $p<0.0007$ vs NT alone; Fig. $1 F)$, suggesting that NT acts via activation of NT receptors.

We then tested the roles of NT receptors (NTS1 and NTS2) in NT-induced enhancement of neuronal excitability. Bath application of the selective NTS1 blocker, SR48693 (1 $\mu \mathrm{M}$, for $10 \mathrm{~min})$, did not significantly alter AP firing frequency ( $98 \pm 6 \%$ of control, $n=6, p=0.68$; data not shown), suggesting that this compound by itself does not modulate AP firing. We then pretreated the slices with SR48692 $(1 \mu \mathrm{M})$ for $\sim 20 \mathrm{~min}$, and the same concentration of SR48692 was continuously bath-applied. In the presence of SR48692, application of NT increased AP firing frequency to a significantly smaller level $(n=6, p=0.001$ vs NT alone, two-way ANOVA; Fig. $2 A$ ), suggesting the requirement of NTS1 receptors. Because PD149163 is a small-molecule NTS1 agonist that crosses the blood-brain barrier (Feifel et al., 2004, 2010; Azmi et al., 2006), we tested the effects of PD149163 on neuronal excitability recorded from stellate neurons in the EC. Bath application of PD149163 (0.25 $\mu \mathrm{M})$ robustly increased the
AP firing frequency $(n=10, p=0.002$; Fig. $2 A)$, further supporting the requirement of NTS1 receptors. However, pretreatment of slices with and continuous bath application of NTS2 receptor antagonist levocabastine $(30 \mu \mathrm{M})$ was without effect on NTinduced facilitation of AP firing frequency ( $n=10, p=0.35$ vs NT alone; Fig. $2 A$ ), suggesting that NTS2 is not necessary for NT-induced facilitation of neuronal excitability. We further tested the roles of NT receptors in NT-induced facilitation of neuronal excitability by using NT receptor KO mice as previously (Maeno et al., 2004). Application of NT did not significantly increase the AP firing frequency in NTS1 KO mice $(n=12$ cells from 4 mice, $p=0.98$; Fig. $2 B$ ), whereas application of NT still robustly increased the AP firing frequency in NTS2 KO $(n=12$ cells from 4 mice, $p<0.0001$; Fig. $2 B$ ) and WT ( $n=10$ cells from 3 mice, $p<0.0001$; Fig. $2 B$ ) mice, further confirming the involvement of NTS1. Consistent with our electrophysiological data, immunoreactivity for NTS1 was mainly detected in the superficial layers (especially layer II) of the EC (Fig. 2C). Western blot showed a single protein band of $\sim 60 \mathrm{kDa}$ in the lysates of the EC prepared from rats and WT mice, corresponding to the molecular mass of NTS1 receptors (Martorana et al., 2006), whereas no band was detected in this range of molecular mass for the lysates of the EC from NTS1 KO mice (Fig. 2D).

NTS1 receptors are coupled to G-proteins. We next tested the roles of G-proteins in NT-induced facilitation of neuronal excitability. Intracellular dialysis of G-protein inhibitor GDP- $\beta$-S (2 $\mathrm{mM}$ ) blocked NT-induced enhancement of AP firing frequency $(n=7, p=0.79$; Fig. $2 E)$. The major intracellular signal activated by NTS1 is PLC $\beta$, which hydrolyzes $\mathrm{PIP}_{2}$ to produce $\mathrm{IP}_{3}$ to facilitate intracellular $\mathrm{Ca}^{2+}$ release and diacylglycerol to activate PKC. We accordingly examined the roles of this pathway. Slices were pretreated with U73122 $(10 \mu \mathrm{M})$, a PLC inhibitor, and the same concentration of U73122 was continuously bath-applied. Under these conditions, application of NT failed to change the AP firing frequency significantly $(n=6, p=0.12$; Fig. $2 E)$, 
A

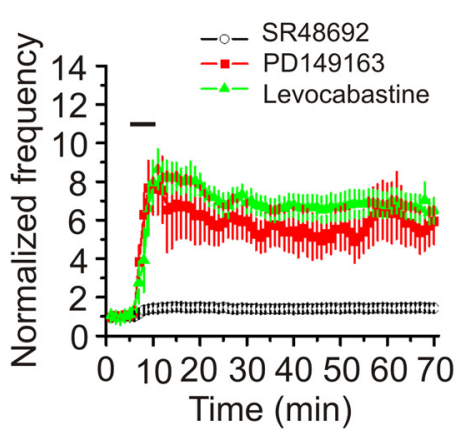

D

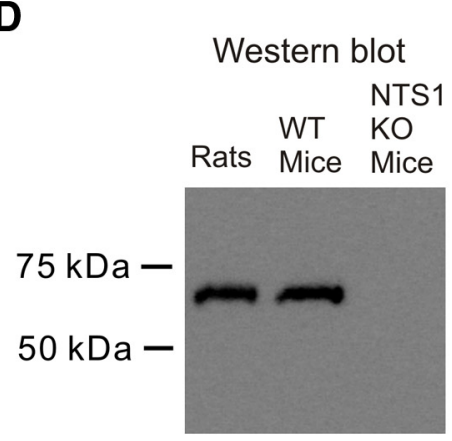

B

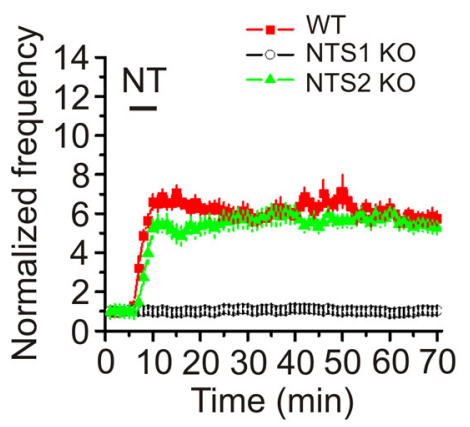

E

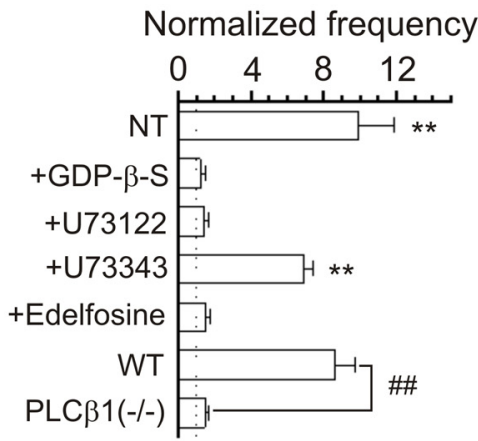

C

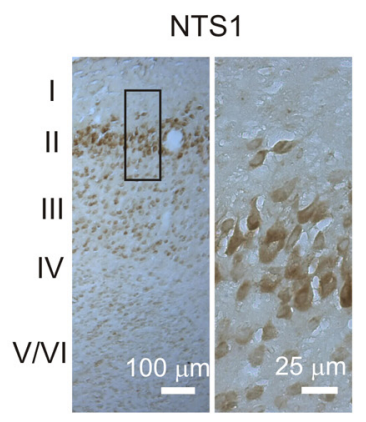

Control

(+ blocking peptide)

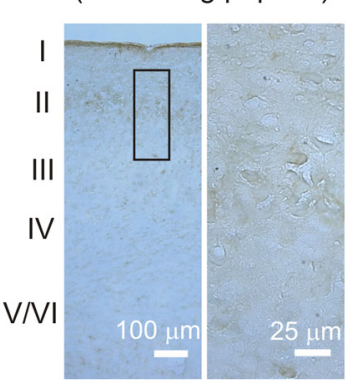

Figure 2. NT-elicited facilitation of AP firing frequency requires the functions of NTS1, PLC $\beta 1$, and PKC. $A$, NT-induced enhancement of AP firing frequency was remarkably reduced in the presence of the selective NTS1 antagonist, SR48692, but insensitive to levocabastine, an NTS2 antagonist. Bath application of the specific NTS1 agonist PD149163 (0.25 $\mu \mathrm{M})$ increased AP firing frequency. Slices were pretreated with SR48692 $(1 \mu \mathrm{M})$ or levocabastine $(30 \mu \mathrm{M})$, and the bath was continuously perfused with the same concentration of the drugs. The horizontal bar represents the period of bath application of NT or PD149163. B, NT-induced facilitation of AP firing frequency disappeared in slices cut from NTS1 K0 mice $(n=12$ cells from 4 mice) but was still observed in slices cut from WT mice ( $n=10$ cells from 3 mice) or NTS2 K0 mice ( $n=12$ cells from 4 mice). C, Immunoreactivity to NTS1 receptors was mainly detected in the superficial layers of the EC. Right, Enlargement of the region marked in the left section. Preabsorption of the NTS1 antibody with the corresponding blocking peptide blocked the detection of the immunoreactivity. D, Western blot demonstrated the expression of NTS1 receptors in the EC. Tissue lysates of the medial EC taken from rats, WT mice, and NTS1 KO mice ( $n=6$ animals) were loaded to the gel and blotted against the NTS1 antibody. A band of $\sim 60 \mathrm{kDa}$ corresponding to the molecular mass of NTS1 was detected in the lysates from rats and WT mice but not in those from NTS1 K0 mice. $\boldsymbol{E}$, Roles of G-proteins and $\mathrm{PLC} \beta 1$ in NT-elicited facilitation of AP firing frequency. ${ }^{* *} p<0.01$ versus baseline. ${ }^{\# \#} p<0.01$. F, Roles of intracellular $\mathrm{Ca}^{2+}$ and PKC in NT-mediated enhancement of AP firing frequency. ${ }^{*} p<$ 0.05 versus baseline. ${ }^{* *} p<0.01$ versus baseline. ${ }^{\# \#} p<0.01$ versus NT alone.

whereas application of U73343 (10 $\mu \mathrm{M})$, the inactive analog, in the same fashion did not significantly alter NT-induced enhancement of AP firing frequency $(n=6, p<0.0001$ vs baseline; Fig. $2 E)$. Similarly, application of edelfosine $(10 \mu \mathrm{M})$, another PLC inhibitor, blocked NT-induced facilitation of AP firing frequency $(n=9, p=0.09$; Fig. $2 E)$. We then used PLC $\beta$ KO mice to further confirm our results. Among the 4 isoforms of PLC $\beta$ (PLC $\beta 1-4)$, PLC $\beta 1$ is expressed in the hippocampal formation (Watanabe et al., 1998). We therefore used PLC $\beta 1 \mathrm{KO}$ mice as previously described (Deng et al., 2006; Lei et al., 2007) to examine the roles of PLC in NT-induced facilitation of AP firing. Application of NT robustly enhanced the AP firing frequency $(n=10$ cells, $p<$ 0.0001 ) in slices cut from 3 WT mice, whereas it increased the AP firing frequency to a significantly smaller level ( $n=13$ cells) in slices cut from 4 PLC $\beta 1$ KO mice $(p<0.0001$ vs WT mice; Fig. $2 E)$. Together, these results demonstrate that NT-mediated enhancement of neuronal excitability requires the function of PLC $\beta 1$. We then tested the roles of PKC and intracellular $\mathrm{Ca}^{2+}$ release in NT-induced facilitation of neuronal excitability. Slices were pretreated with GF109203X ( $1 \mu \mathrm{M})$ and Ro318220 (1 $\mu \mathrm{M})$ separately, and the same concentrations of the PKC inhibitors were continuously bath-applied. Under these circumstances, application of NT failed to increase AP firing frequency significantly in the presence of GF109203X $(n=6, p=0.2$; Fig. $2 F)$ or $\operatorname{Ro} 318220(n=6, p=0.83$; Fig. $2 F)$, demonstrating the involvement of PKC. Because PKC is an upstream activator of MEK/ERK in some cell types (Hu and Gereau, 2003), we also tested whether MEK/ERK is required for NT-induced increase in AP firing frequency. Slices were pretreated with the selective MEK/ERK inhibitor PD98059 (50 $\mu \mathrm{M})$ for $>2 \mathrm{~h}$ and the extracellular solution continued to contain the same concentration of PD98059. Under these circumstances, bath application of NT still enhanced the AP firing frequency to a comparable level $(n=5, p=0.02$; Fig. $2 F)$, suggesting that MEK/ERK activity is not required for NTinduced facilitation of neuronal excitability. To test the involvement of $\mathrm{IP}_{3}$ receptors, we included xestospongin $\mathrm{C}\left(5 \mu \mathrm{M}, \mathrm{IP}_{3}\right.$ receptor inhibitor) in the recording pipettes and waited for $\sim 20$ min after the formation of whole-cell configuration. In this condition, application of NT still increased the AP firing frequency to a comparable level ( $n=6, p=0.83$ vs NT alone; Fig. $2 F)$. Similarly, depletion of intracellular $\mathrm{Ca}^{2+}$ stores by including thapsigargin $(10 \mu \mathrm{M})$ in the pipettes for $20 \mathrm{~min}$ did not significantly alter NT-induced facilitation of AP firing frequency $(n=6, p=$ 0.41 vs NT alone; Fig. $2 F$ ). These results suggest that intracellular $\mathrm{Ca}^{2+}$ release is not required for NT-induced increases in AP firing. We then included BAPTA $(10 \mathrm{~mm})$ in the recording pipettes to chelate intracellular $\mathrm{Ca}^{2+}$. In the presence of BAPTA, bath application of NT increased the AP firing frequency to a significantly smaller level $(n=7, p=0.007$ vs NT alone; Fig. $2 F$ ). Because NT still significantly increased the AP firing frequency in the extracellular solution without $\mathrm{Ca}^{2+}$ (prepared by replacing extracellular $\mathrm{Ca}^{2+}$ with the same con- 
centration of $\mathrm{Mg}^{2+}$ and adding $1 \mathrm{~mm}$ EGTA, $n=9, p=0.013$; Fig. $2 F$ ), one explanation for the effect of BAPTA is that a certain basal level of intracellular $\mathrm{Ca}^{2+}$ is required for the activation of signaling molecules, such as PLC $\beta$ and PKC.

NT-induced facilitation of AP firing is generated by membrane depolarization We recorded RMPs in the presence of TTX $(0.5 \mu \mathrm{M})$ to block AP firing. Application of NT generated membrane depolarization (control: $-57.7 \pm 1.2 \mathrm{mV}, \mathrm{NT}$ : $-53.2 \pm 2.0 \mathrm{mV}, n=6, p=0.006$; Fig. $3 A)$ and significantly increased the input resistance assessed by injection of a negative current ( $-50 \mathrm{pA}$ for $500 \mathrm{~ms}$ ) before $(115 \pm 6 \mathrm{M} \Omega)$ and after $(133 \pm 6 \mathrm{M} \Omega) \mathrm{NT}$ application $(n=6, p=0.002$; Fig. $3 A$, inset). We then recorded the HCs at -55 $\mathrm{mV}$, a potential close to the RMPs of these neurons. Application of NT generated a net inward $\mathrm{HC}(-44.5 \pm 5.4 \mathrm{pA}, n=16$, $p<0.001$; Fig. $3 B$ ), indicating that NT increases neuronal excitability by generating membrane depolarization.

Cationic channels are not involved in NT-induced membrane depolarization We probed the ionic mechanisms whereby NT generates membrane depolarization. NT could cause depolarization by opening a cationic conductance and/or by inhibiting a background $\mathrm{K}^{+}$conductance. We accordingly tested these possibilities by replacing the intracellular $\mathrm{K}^{+}$ with $\mathrm{Cs}^{+}$. Application of NT failed to induce an increase in inward HCs when intracellular $\mathrm{K}^{+}$was replaced with $\mathrm{Cs}^{+}$ $(4.6 \pm 1.9 \mathrm{pA}, n=7, p=0.06$; Fig. $3 B$ ), suggesting the involvement of $\mathrm{K}^{+}$channels. We further examined whether there is a role for cationic channels by performing the following experiments. First, we replaced extracellular $\mathrm{NaCl}$ with NMDG-Cl and $\mathrm{Ca}^{2+}$ with $\mathrm{Mg}^{2+}$ because, if cationic channels are involved, influx of extracellular $\mathrm{Na}^{+}$and $\mathrm{Ca}^{2+}$ would be the ions to mediate the inward currents. However, in this condition, application of NT still induced a comparable inward $\mathrm{HC}$ ( $n=8, p=0.45$ vs the inward $\mathrm{HCs}$ in control condition; Fig. $3 B$ ). Second, we examined the effects of other cationic channel blockers. Pretreatment of slices with and continuous bath application of SKF96365 $(50 \mu \mathrm{M}$, an inhibitor of receptor-operated cationic channels, $n=$ $6, p=0.85), \mathrm{Gd}^{3+}(10 \mu \mathrm{M}, n=7, p=0.37), \mathrm{La}^{3+}(10 \mu \mathrm{M}, n=7$, $p=0.65)$, or ZD7288 (20 $\mu \mathrm{M}$, an inhibitor of Ih channels, $n=6$, $p=0.57)$, failed to exert significant effects on NT-induced increases in inward HCs, demonstrating that NT-induced depolar-

$\mathbf{E}$
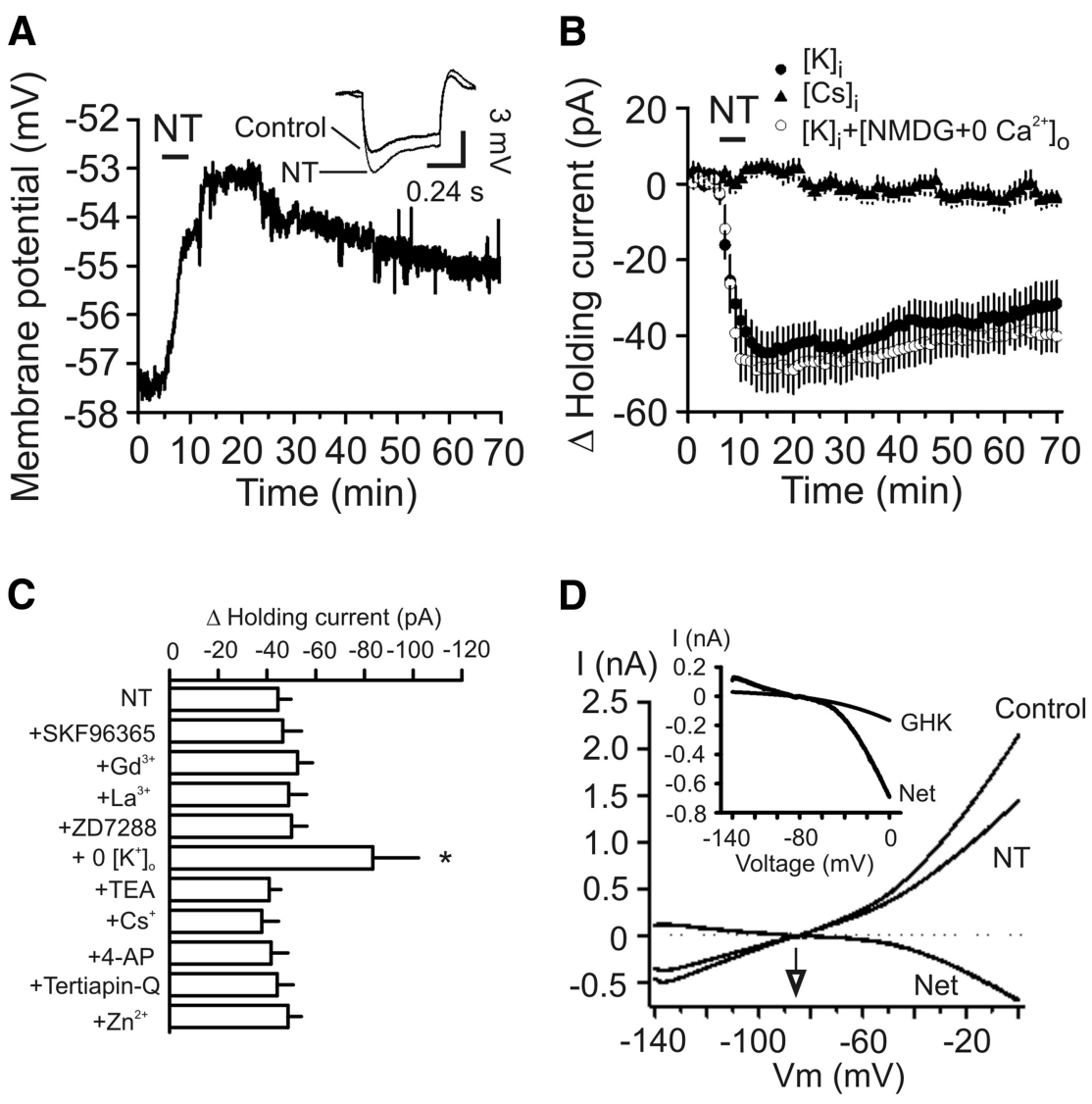

$\mathbf{F}$
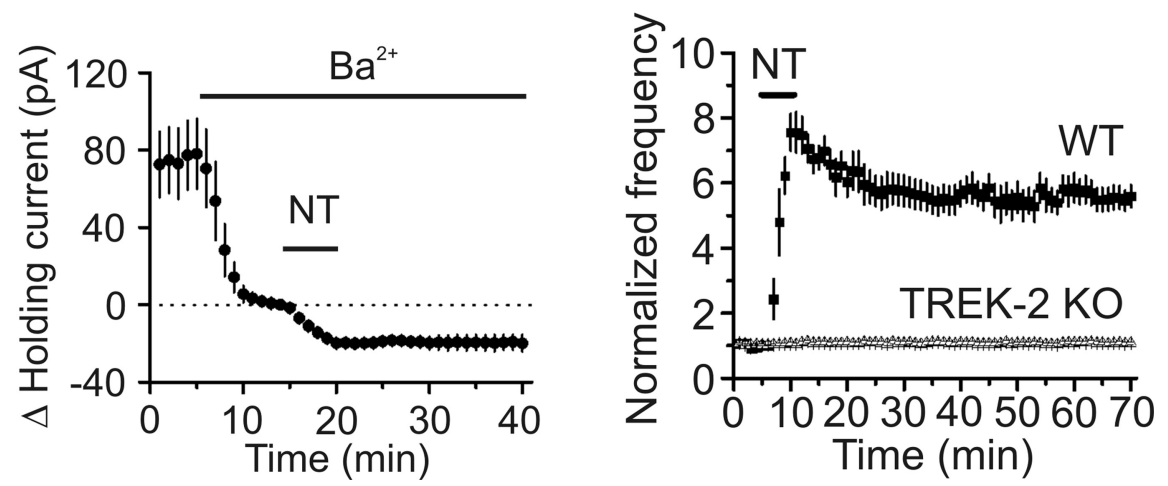

Figure 3. NT increases AP firing frequency by inhibition of TREK-2 channels. A, RMP recorded from a stellate neuron in current clamp before, during, and after the application of NT. Inset, Voltage change in response to the injection of a hyperpolarizing current $(-50 \mathrm{pA}, 500$ $\mathrm{ms}$ ) from the same cell before and after application of NT. NT induced membrane depolarization and increased input resistance. $\boldsymbol{B}$, Bath application of NT induced an inward $\mathrm{HC}$ when the recording pipettes contained $\mathrm{K}^{+}$-gluconate, whereas replacing the intracellular $\mathrm{K}^{+}$with $\mathrm{Cs}^{+}$blocked NT-induced increases in inward HCs. Replacement of extracellular NaCl with NMDG-Cl and $\mathrm{Ca}^{2+}$ with the same concentration of $\mathrm{Mg}^{2+}$ failed to alter significantly NT-induced increases in inward HCs in intracellular solution containing $\mathrm{K}^{+}$-gluconate. C, NT-induced increases in inward HCs were insensitive to the extracellular application of blockers for nonselective cationic (SKF96365, $\mathrm{Gd}^{3+}, \mathrm{La}^{3+}$ ), lh (ZD7288), and $\mathrm{K}^{+}\left(\mathrm{TEA}, \mathrm{CS}^{+}, 4-\mathrm{AP}\right.$, tertiapin-Q) channels and Zn ${ }^{2+}$, but depletion of extracellular $\mathrm{K}^{+}$significantly enhanced NT-induced $H C S .{ }^{*} p<0.05$ versus NT alone. $D$, Voltage-current relationship induced by a ramp protocol from -140 to $0 \mathrm{mV}$ at a speed of $0.1 \mathrm{mV} / \mathrm{ms}$ before and during the application of NT. Subtraction of the current before the application of NT generated a net current. The traces were averages from 5 cells. The reversal potential was $\sim-87 \mathrm{mV}$, close to the calculated $\mathrm{K}^{+}$reversal potential $(-85.4 \mathrm{mV})$. Inset, NT-induced net current could not be fit by GHK equation, suggesting that the channels inhibited by NT were not TASK channels. $E$, Inclusion of $\mathrm{Ba}^{2+}$ in the extracellular solution induced an inward HC but significantly reduced NT-induced increases in inward HCS. F, Bath application of NT failed to increase AP firing frequency in slices cut from TREK-2 KO mice but still robustly enhanced AP firing frequency in slice cut from WT mice. ization is not mediated by activation of a cationic conductance (Fig. 3C).

NT has been reported to inhibit $\mathrm{Na}^{+} / \mathrm{K}^{+}$pump (López Ordieres and Rodríguez de Lores Arnaiz, 2000), and this pump 
normally creates a concentration gradient by moving $3 \mathrm{Na}^{+}$out of the cell and $2 \mathrm{~K}^{+}$into the cells. NT-mediated inhibition of this pump should create a net accumulation of $\mathrm{Na}^{+}$inside the cells resulting in depolarization. Because extracellular $\mathrm{K}^{+}$is necessary for the function of the $\mathrm{Na}^{+} / \mathrm{K}^{+}$pump, we replaced the extracellular $\mathrm{K}^{+}(3.5 \mathrm{~mm})$ with the same concentration of $\mathrm{Na}^{+}$. Instead of reducing the inward $\mathrm{HCs}$, removal of extracellular $\mathrm{K}^{+}$resulted in a significant increase in $\mathrm{HCs}(-83.5 \pm 18.8 \mathrm{pA}, n=6, p=$ 0.012 vs NT alone, Fig. $3 C$ ), suggesting that NT-induced depolarization is unlikely the result of the inhibition of $\mathrm{Na}^{+} / \mathrm{K}^{+}$ pump but may be relevant to $\mathrm{K}^{+}$movement across the membrane (see below).

\section{NT generates membrane depolarization by inhibiting TREK-2 channels}

We further probed the involvement of $\mathrm{K}^{+}$conductance. We used a ramp protocol (from -140 to $0 \mathrm{mV}$ ) to construct the voltagecurrent relationship before and just after the application of NT. The intracellular solution contained $\mathrm{K}^{+}$-gluconate, and the extracellular $\mathrm{K}^{+}$concentration was $3.5 \mathrm{~mm}$. Under these circumstances, application of NT induced a current with a reversal potential of $-86.7 \pm 1.5 \mathrm{mV}(n=5$; Fig. $3 D)$. The measured reversal potential was close to the calculated $\mathrm{K}^{+}$reversal potential $(-85.4 \mathrm{mV})$ in our recording condition further confirming that NT increases neuronal excitability by inhibiting a background $\mathrm{K}^{+}$conductance. We next characterized the properties of the involved $\mathrm{K}^{+}$channels. NT-induced increases in inward HCs were not significantly changed by including tetraethylammonium (TEA, $10 \mathrm{~mm}, n=9, p=0.66), \mathrm{Cs}^{+}(3 \mathrm{mM}, n=6, p=$ 0.51 ), or 4 -aminopyridine (4-AP, $2 \mathrm{mM}, n=6, p=0.78$ ) in the extracellular solution (Fig. $3 C$ ). Application of the selective inward rectifier $\mathrm{K}^{+}$channel inhibitor tertiapin-Q (100 nM) did not significantly alter NT-induced changes in $\mathrm{HCs}(n=7, p=0.97$; Fig. 3C). Furthermore, NT-induced increases in inward HCs were not sensitive to extracellular application of $\mathrm{Zn}^{2+}(100 \mu \mathrm{M}$, $n=8, p=0.63$; Fig. $3 C$ ).

The above results prompted us to test the role of the two-pore domain $\mathrm{K}^{+}\left(\mathrm{K}_{2 \mathrm{P}}\right)$ channels because $\mathrm{K}_{2 \mathrm{P}}$ channels are involved in controlling RMPs and usually insensitive to the classic $\mathrm{K}^{+}$channel blockers (Lesage and Lazdunski, 2000; Bayliss et al., 2003; Lesage, 2003). Because some $\mathrm{K}_{2 \mathrm{P}}$ channels are sensitive to $\mathrm{Ba}^{2+}$, we tested the roles of $\mathrm{Ba}^{2+}$ in NT-induced increases in inward HCs. Application of $\mathrm{Ba}^{2+}(3 \mathrm{mM})$ alone generated an inward HC $(-78.1 \pm 18.2 \mathrm{pA}, n=9, p=0.003$; Fig. $3 E)$, and it also significantly inhibited NT-induced inward HCs $(-20.1 \pm 2.1 \mathrm{pA}, n=$ $9, p=0.001$ vs NT alone; Fig. $3 E$ ), suggesting the involvement of $\mathrm{Ba}^{2+}$-sensitive $\mathrm{K}_{2 \mathrm{P}}$ channels.

Among the $\mathrm{K}_{2 \mathrm{P}}$ channels, TASK-1 (Han et al., 2002), TASK-3 (Kim et al., 2000; Han et al., 2002), TREK-1 (Fink et al., 1996; Ma et al., 2011), TREK-2 (Bang et al., 2000; Han et al., 2002), and TWIK-1 (Lesage et al., 1996) and TRESK (Sano et al., 2003; Kang et al., 2004) are sensitive to $\mathrm{Ba}^{2+}$. TRESK channels are unlikely to be involved because they are expressed in the spinal cord and other organs but not in the brain (Sano et al., 2003; Kang et al., 2004). Among the remaining $5 \mathrm{~K}_{2 \mathrm{P}}$ channels, the $\mathrm{EC}$ expresses higher densities of TASK-1 and TREK-2 (Deng et al., 2009). Because TASK channel currents show GHK-type rectification (Lesage and Lazdunski, 2000; Bayliss et al., 2003) and fitting of the NT-induced net I-V curve by GHK equation demonstrated remarkable deviation (Fig. 3D, inset), suggesting that TASK-1 channels are unlikely to be the target for NT, we focused on TREK-2 channels by using TREK-2 KO mice as described previously (Guyon et al., 2009). Application of NT induced an inward
HC $(-38.8 \pm 6.1 \mathrm{pA}, n=9$ cells; data not shown $)$ and robustly increased the firing frequency of APs $(n=9$ cells, $p<0.001$; Fig. $3 F$ ) in slices cut from 3 WT mice, whereas it failed to induce an inward HC $(-3.7 \pm 2.5 \mathrm{pA}, n=9$ cells, $p=0.19$; data not shown $)$ and did not increase AP firing frequency $(n=9$ cells, $p=0.32$; Fig. $3 F$ ) in slices cut from 3 TREK-2 KO mice. However, the RMPs of stellate neurons in TREK-2 KO mice $(-59.7 \pm 1.1 \mathrm{mV}$, $n=9$ cells from 3 mice) were not significantly different ( $p=$ 0.25 ) from those of WT mice ( $-61.4 \pm 0.9 \mathrm{mV}, n=9$ cells from 3 mice; data not shown). Together, these data indicate that NT facilitates neuronal excitability by inhibiting TREK- 2 channels.

\section{Activation of NTS1 inhibits TREK-2 currents via PLC/PKC pathway in HEK293 cells cotransfected with NTS1 and TREK- 2 channels}

We further probed the involvement of TREK-2 channels by using whole-cell recordings from the HEK293 cells expressing NTS1 and TREK-2 channels (Deng et al., 2007, 2009; Xiao et al., 2009). Bath application of NT $(0.25 \mu \mathrm{M})$ induced an inward HC recorded at $-55 \mathrm{mV}$ in HEK293 cells cotransfected with NTS1 and TREK-2 channels $(n=8, p=0.002$; Fig. $4 A, B)$. However, bath application of NT $(0.25 \mu \mathrm{M})$ did not change the HCs recorded at $-55 \mathrm{mV}$ in HEK293 cells transfected with TREK-2 channels alone $(n=5, p=0.82$; Fig. $4 B)$ or NTS1 alone $(n=6, p=0.86$; Fig. $4 B$ ). We further determined the roles of PLC, PKC, and intracellular $\mathrm{Ca}^{2+}$ release in NT-mediated depression of TREK-2 channels in HEK293 cells cotransfected with NTS1 and TREK-2 channels. NT-induced inward HCs were significantly reduced in the presence of PLC inhibitor (U73122, $10 \mu \mathrm{M}, n=8, p<0.0001$ ) compared with those in the presence of the inactive analog (U73343, $10 \mu \mathrm{M}, n=7$; Fig. 4C). Similarly, treatment of the cells with another PLC inhibitor (edelfosine, $10 \mu \mathrm{M}, n=8, p=0.001$ ) significantly reduced NT-induced inward HCs compared with control (Fig. 4C). Furthermore, NT-induced inward HCs were significantly reduced by pretreatment of transfected cells with the selective PKC inhibitor (GF109203X, $1 \mu \mathrm{M}, n=5, p=0.007$ ) but were unaffected by intracellular application of xestospongin C ( 1 $\mu \mathrm{M}, \mathrm{IP}_{3}$ receptor inhibitor, $n=8, p=0.08$; Fig. $4 C$ ) or thapsigargin $(10 \mu \mathrm{M}, n=5, p=0.051$; Fig. $4 C)$. However, intracellular application of BAPTA $(10 \mathrm{~mm})$ significantly reduced NTinduced inward HCs $(n=6, p=0.008$; Fig. $4 C)$. These results demonstrate that NT-induced depolarization requires the functions of PLC and PKC. One explanation for the effect of BAPTA is that intracellular $\mathrm{Ca}^{2+}$ may be required for the functions of the signaling molecules, such as PLC and PKC.

\section{Application of NT to entorhinal slices increases serine phosphorylation of TREK-2 channels}

The above experiments suggest that activation of NTS1 inhibits TREK-2 channels via PKC-dependent phosphorylation of TREK-2 channels. In accordance with our results, TREK-2 channels are phosphorylated and inhibited by PKC on serine 326 (S326) and serine 359 (S359) (Gu et al., 2002; Kang et al., 2006; Kréneisz et al., 2009). We next tested the roles of PKC-dependent phosphorylation of these two sites in NT-mediated depression of TREK-2 channels. Because mutation of S326 and S359 to alanine blocked PKC-mediated inhibition of TREK-2 channels (Kang et al., 2006; Kréneisz et al., 2009), we cotransfected HEK293 cells with NTS1 and the TREK-2 mutant in which both serine 326 and serine 359 were mutated to alanine (S326A/S359A) (Kang et al., 2006; Kréneisz et al., 2009). Application of NT to the HEK293 cells cotransfected with NTS1 and TREK-2 mutant induced sig- 
A

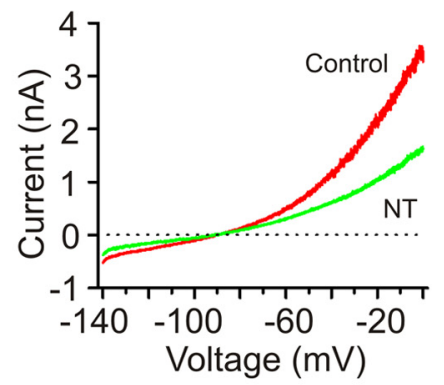

D

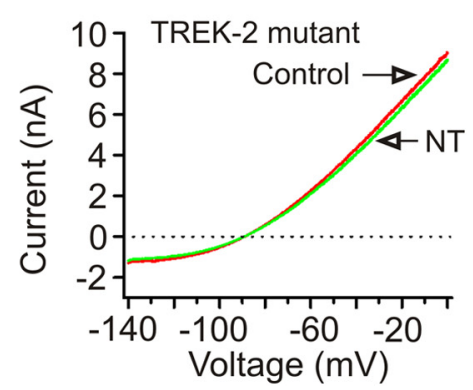

B

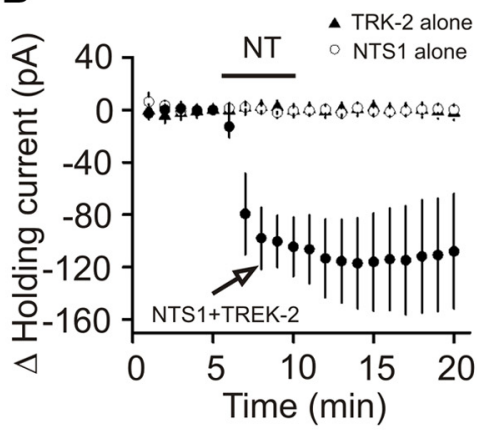

$\mathbf{E}$

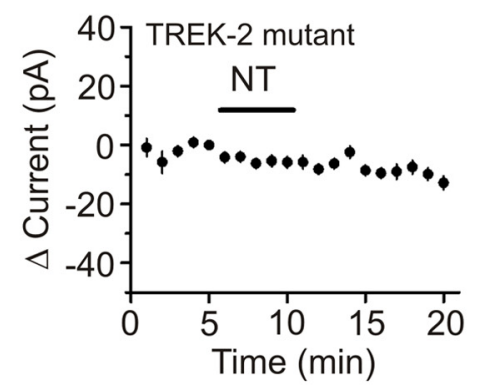

C

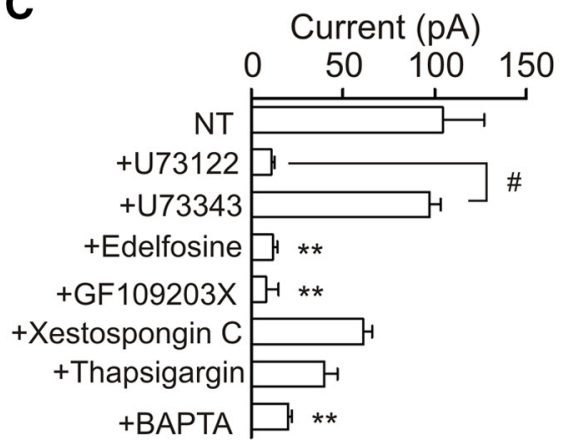

$\mathbf{F}$

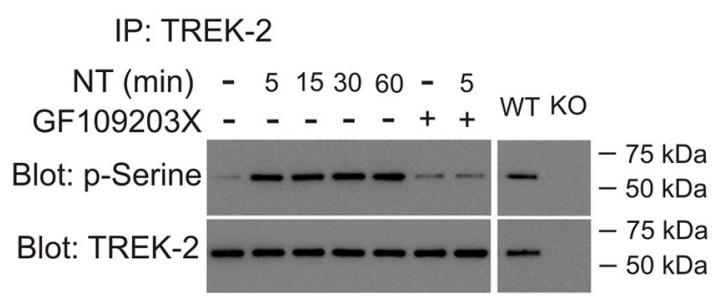

Figure 4. Activation of NTS1 receptors resulted in phosphorylation and inhibition of TREK-2 channels. A, I-V curves recorded by a ramp protocol from $-140 \mathrm{mV}$ to $0 \mathrm{mV}$ in a HEK293 cell cotransfected with NTS1 and TREK-2 channels before (red) and during (green) the application of NT. B, Pooled time course of the HCs recorded at $-55 \mathrm{mV}$ from HEK293 cells transfected with NTS1 alone, or TREK-2 channels alone or NTS1 together with TREK-2 channels in response to bath application of NT. Bath application of NT induced an inward HC only in HEK293 cells cotransfected with NTS1 and TREK-2 channels. C, NT-mediated inhibition of TREK- 2 currents was mediated via activation of PLC and PKC in HEK293 cells cotransfected with NTS1 and TREK- 2 channels. ${ }^{* *} p<0.01$ versus NT alone. ${ }^{\#} p<0.05$. D, I-V curves in a HEK293 cell cotransfected with NTS1 and TREK-2 mutant before (red) and during (green) the application of NT. $\boldsymbol{E}$, Pooled time course of the HCs recorded from HEK293 cells cotransfected with NTS1 and TREK-2 mutant in response to NT. NT did not significantly alter the HCs. $\boldsymbol{F}$, Persistent phosphorylation of TREK-2 channels on serine was detected in the lysate of the rat EC immunoprecipitated with antibody to TREK-2 channels. As a control, application of the same experimental procedures induced phosphorylation of TREK-2 channels in the samples prepared from WT mice but not in those prepared from TREK-2 KO mice. The molecular mass of TREK-2 channels was $\sim 59 \mathrm{kDa}$.

nificantly smaller HCs $(-8.2 \pm 1.4 \mathrm{pA}, n=7, p=0.002$ vs NT-induced HCs in the cells transfected with WT TREK-2; Fig. $4 D, E)$. These data demonstrate that NT-induced depression of TREK-2 channels is mediated by PKC-dependent phosphorylation of TREK-2 channels on S326 and S359.

We further corroborated NT-induced phosphorylation of TREK-2 channels in the EC. We treated entorhinal slices for 5 min with or without NT in the absence or presence of the PKC inhibitor (GF109203X). Slices were then lysed, and the lysates were immunoprecipitated with TREK-2 antibody. The immunoprecipitates were resolved by SDS-PAGE and Western blotted with anti-phosphoserine antibody. As shown in Figure $4 F$, treatment of slices with NT for 5 min induced persistent increases in the phosphorylation of TREK-2 channels when the slices were kept in NT-free solution for $\sim 1 \mathrm{~h}(n=3$ experiments, $p<0.01$ for each). Pretreatment of slices with GF109203X blocked NTinduced increases in the phosphorylation of TREK-2 channels ( $n=3$ experiments, $p=0.8)$. As a control, treatment of slices cut from WT mice with NT for 5 min induced phosphorylation of TREK-2 channels, whereas no band was detected in the samples prepared from the TREK-2 KO mice with the same experimental procedures (Fig. 4F). These results demonstrate that NTinduced depression of TREK-2 channels is mediated by PKCdependent phosphorylation of TREK-2 channels.

NT enhances EPSP-AP coupling in layer II stellate neurons All the above experiments regarding the effects of NT on AP firing were performed by injection of small positive current to elevate the RMP to just above threshold to induce AP firing. We next tested whether NT by itself could elevate the RMPs of stellate neurons to above the threshold to induce AP firing. In 10 stellate neurons, there was no spontaneous AP firing at rest. Application of NT induced AP firing in 6 of the 10 stellate neurons. The AP firing frequency reached maximal in $\sim 5$ min after the beginning of NT application (141 $\pm 26 \mathrm{APs} / \mathrm{min}, n=6, p=0.003$; Fig. $5 A, B)$. Whereas the AP firing frequency was declined after wash in NT-free extracellular solution, there was still AP firing after wash for $1 \mathrm{~h}(34 \pm 7 \mathrm{APs} / \mathrm{min}, n=6, p=0.004$; Fig. $5 A, B)$. Application of NT to the remaining 4 stellate neurons failed to induce AP firing but significantly elevated the RMPs (control: $-58.7 \pm 1.3 \mathrm{mV}, \mathrm{NT}:-55.2 \pm 1.6 \mathrm{mV}, n=4, p=0.012$; data not shown). We then tested the effects of NT on EPSP-AP coupling in layer II stellate neurons by placing a stimulation electrode in layer I to stimulate the glutamatergic inputs. Application of NT induced the depolarization of the baseline of the EPSPs (control: $-59.5 \pm 1.3 \mathrm{mV}, \mathrm{NT}:-54.9 \pm 1.6 \mathrm{mV}, n=5, p=0.0009$; Fig. $5 C, D)$ and facilitated EPSP-AP coupling $(n=5, p=0.0003$; Fig. $5 C, D)$. To differentiate the presynaptic and postsynaptic effects of NT, we replicated the experiment by using $\mathrm{Cs}^{+}$-gluconatecontaining intracellular solution to block the depolarizing effect of NT on stellate neurons. Under these circumstances, NT failed to altered the slope $(101 \pm 2 \%$ of control, $n=9, p=0.55$; Fig. $5 E, F)$ of the EPSPs, suggesting that NT-mediated facilitation of EPSP-AP coupling was not mediated by modulating presynaptic glutamate release, but because of its depolarizing effect on postsynaptic stellate neurons. 
A

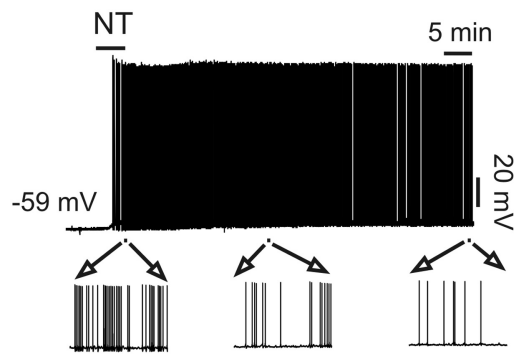

C

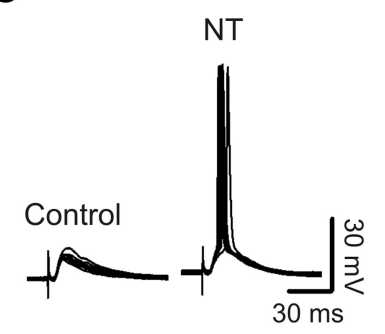

E

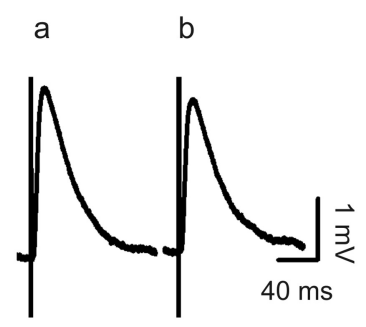

B

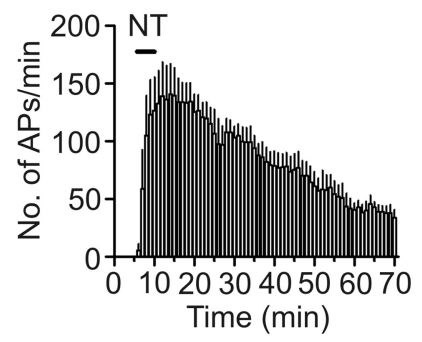

D

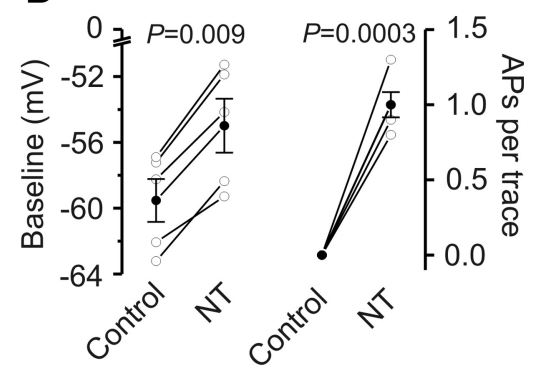

F

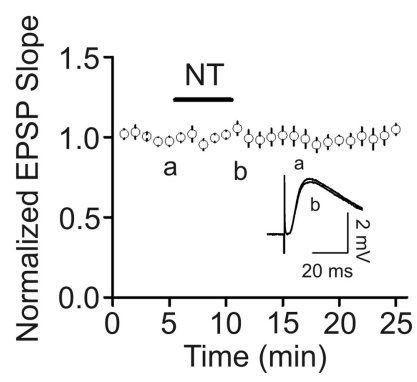

Figure 5. NT increases EPSP-AP coupling. $\boldsymbol{A}$, NT initiated AP firing from the RMP in a stellate neuron. Bottom, Expanded APs indicated by the horizontal bar at different times. $\boldsymbol{B}$, Pooled time course of AP firing frequency before, during, and after the application of NT. Although the number of APs declined during wash, there was still AP firing after wash in NT-free extracellular solution for 1 h. C, NT increased EPSP-AP coupling. Left, Ten consecutive EPSPs recorded from a stellate neuron by placing a stimulation electrode in layer I. Right, Ten EPSP/APs recorded from the same neuron after $5 \mathrm{~min}$ application of NT. D, Pooled data from 5 stellate neurons showing that NT induces depolarization of the baseline (left) and enhances the number of APs averaged from 10 consecutive traces (right). $\boldsymbol{E}$, Traces averaged from 10 consecutive EPSPs recorded using a $\mathrm{Cs}^{+}{ }^{+}$-gluconate-containing intracellular solution before (a) and after (b) the application of NT. $\boldsymbol{F}$, Pooled time course of EPSP slopes in response to NT application. Inset, Two expanded EPSPs averaged from 10 consecutive traces taken from the time points indicated in the figure to show that NT exerts no effects on EPSP slopes.

\section{NT facilitates spatial learning and memory in Barnes Maze Test}

We next probed the roles of NT in the modulation of spatial learning and memory because layer II of the medial EC is predominated by "grid" cells (Sargolini et al., 2006; Hafting et al., 2008; Brandon et al., 2011; Burgalossi et al., 2011), which are essential for spatial navigation, and NT-induced excitation of these neurons likely plays an important role in spatial learning and memory. We examined the roles of NT in spatial learning and memory using the Barnes Maze Test. Although we previously used Morris Water Maze and measured the spatial learning and memory of animals (Deng et al., 2009), the advantage of Barnes Maze Test is that it is less physically taxing and less stressful to animals. After $\sim 15$ min after microinjection each day, rats were trained for 5 consecutive days ( 3 trials per day). On day 12, a probe trial was conducted without the escape box to measure the memory retention ability of the rats (Fig. $6 A, B$ ). Both the escape latency $\left(F_{(4,36)}=10.29, p<0.001\right.$; Fig. $6 C)$ and travel distance $\left(F_{(4,36)}=9.76, p<\right.$ 0.001 ; Fig. $6 D$ ) of rats to locate the escape box were progressively reduced during the training sessions in control rats $\mathrm{mi-}$ croinjected bilaterally with saline $(0.9 \%$ $\mathrm{NaCl}, 1 \mu \mathrm{l} /$ side) into the EC. Bilateral microinjection of NT at the dose of 0.01 $\mathrm{nmol}(1 \mu \mathrm{l} /$ side $)$ into the EC failed to significantly change the spatial learning and memory of the rats compared with that of the rats injected with saline (latency: $F_{(1,16)}=1.55, p=0.23$; Fig. $6 C$; distance: $F_{(1,16)}=1.21, p=0.29$; Figure $\left.6 D\right)$. However, bilateral microinjection of $\mathrm{NT}$ at doses of $0.1 \mathrm{nmol}(1 \mu \mathrm{l} /$ side $)$ and $0.3 \mathrm{nmol}$ (1 $\mu \mathrm{l} /$ side) into the EC significantly decreased the escape latency $(0.1 \mathrm{nmol}$ : $F_{(1,16)}=5.46, p=0.03 ; 0.3 \mathrm{nmol}: F_{(1,18)}=$ 26.06, $p<0.001$; Figure $6 C)$ and the distance traveled $\left(0.1 \mathrm{nmol}: F_{(1,16)}=13.89\right.$, $p=0.002 ; 0.3$ nmol: $F_{(1,18)}=37.16, p<$ 0.0001 ; Figure $6 D$ ) compared with those of the rats injected with saline demonstrating that NT enhances spatial learning and memory. Figure $6 B$ displays the typical traces of rats injected with saline (upper) and NT (lower) on day 1 (left) and day 5 (middle) and day 12 (probe trial, right). Furthermore, NT significantly increased the percentage of time spent in the target quadrant in the probe trial measured on day 12 (Fig. 6E). Together, these data indicate that NT facilitates spatial learning and memory of rats.

We then tested the involvement of NT receptors in NT-induced enhancement of spatial learning and memory by using the NT receptor KO mice. We initially tested the effects of NT on facilitation of spatial learning and memory in WT mice. Bilateral microinjection of NT $(0.3 \mathrm{nmol})$ into the EC of WT mice significantly reduced the escape latency $\left(F_{(1,17)}=17.17, p<\right.$ 0.001 ; Fig. $\left.7 A, B_{1}\right)$ and the distance traveled $\left(F_{(1,17)}=14.88, p=0.001\right.$; Fig. $\left.7 B_{2}\right)$ compared with those of the WT mice injected with saline. Moreover, NT also significantly increased the percentage of time spent in the target quadrant in the probe trial measured on day 12 (Fig. $7 A-B_{3}$ ), indicating that NT facilitates spatial learning and memory of mice as well. We also tested the roles of PD149163, the small-molecule NTS1 agonist that can cross the blood-brain barrier, in spatial learning and memory in WT mice. Bilateral microinjection of PD149163 (0.3 nmol) into the EC of WT mice significantly reduced the escape latency $\left(F_{(1,17)}=12.35, p=\right.$ 0.003; Fig. $\left.7 B_{1}\right)$ and the distance traveled $\left(F_{(1,17)}=11.67, p=\right.$ 0.003 ; Fig. $7 B_{2}$ ) but significantly increased the percentage of time spent in the target quadrant in the probe trial (Fig. $7 B_{3}$ ) compared with those of the WT mice injected with saline suggesting that activation of NTS1 facilitates spatial learning and memory. Likewise, microinjection of NT $(0.3 \mathrm{nmol})$ into the EC of NTS2 KO mice significantly reduced the escape latency $\left(F_{(1,15)}=6.32, p=\right.$ 0.02; Fig. $\left.7 C_{1}\right)$ and the distance traveled $\left(F_{(1,15)}=21.27, p<\right.$ 
0.001; Fig. $7 C_{2}$ ) compared with those of the NTS2 KO mice injected with saline. Similarly, NT also significantly increased the percentage of time spent in the target quadrant in the probe trial for NTS2 KO mice (Fig. $7 C_{3}$ ) indicating that NTS2 is not required in NT-induced facilitation of spatial learning and memory. However, microinjection of the same dose of NT into the EC of NTS1 KO mice failed to change significantly the escape latency $\left(F_{(1,16)}=0.004, p=0.95\right.$; Fig. $\left.7 C_{1}\right)$ and the distance traveled $\left(F_{(1,16)}=0.38, p=\right.$ 0.55; Fig. $7 C_{2}$ ) compared with those of the NTS1 KO mice injected with saline. NT failed to significantly alter the percentage of time spent in the target quadrant in the probe trial in NTS1 $\mathrm{KO}$ mice (Fig. $7 \mathrm{C}_{3}$ ) demonstrating that NT facilitates spatial memory via activation of NTS1. Furthermore, compared with the NTS2 KO mice injected with saline, NTS1 KO mice injected with saline showed significantly increased latency $\left(F_{(1,15)}=13.33, p=\right.$ 0.0024; Fig. $\left.7 C_{1}\right)$ and lengthened distance $\left(F_{(1,15)}=9.31, p=0.008\right.$; Fig. $\left.7 C_{2}\right)$. However, there was a statistically insignificant difference for the time spent in the target quadrant measured at day 12 between the NTS1 KO mice injected with saline and the NTS2 KO mice injected with saline $\left(p=0.24\right.$; Fig. $\left.7 C_{3}\right)$. These results suggest that endogenously released NT also facilitates spatial learning and memory, although it may exert less effect on memory retention (see Discussion).

\section{PKC-induced depression of TREK-2} channels is required for NT-mediated facilitation of spatial learning

Because our cellular physiology data demonstrate that PKC-induced depression of TREK-2 channels is responsible for NTinduced enhancement of neuronal excitability, we next tested whether the functions of PKC and TREK-2 channels are required for NT-induced facilitation of spatial learning. Microinjection of NT after the injection of the selective PKC inhibitor, GF109203X (50 pmol), into the EC of the mice significantly lengthened the escape latency $\left(F_{(1,16)}=5.97, p=0.027\right.$; Fig. $\left.8 A_{1}\right)$ and travel distance $\left(F_{(1,16)}=19.37, p<0.0001\right.$; Fig. $\left.8 A_{2}\right)$, compared with those of the mice microinjected with vehicle (DMSO) and NT. The percentage of time spent in the target quadrant in mice injected with GF109203X and NT was also significantly attenuated compared with that of the mice injected with vehicle and NT (Fig. $8 A_{3}$ ). These data together demonstrate that PKC is required for NT-induced increases in spatial learning. Moreover, neither the escape latency $\left(F_{(1,14)}=0.22, p=0.65\right.$; Fig. $\left.8 B_{1}\right)$ nor the travel distance $\left(F_{(1,14)}=0.11, p=0.75\right.$; Fig. $\left.8 B_{2}\right)$ in TREK-2 KO mice injected with NT was significantly different from those of the TREK-2 KO mice injected with saline, whereas these parameters were still significantly reduced in WT mice injected with NT compared with those of the WT mice injected with saline

B
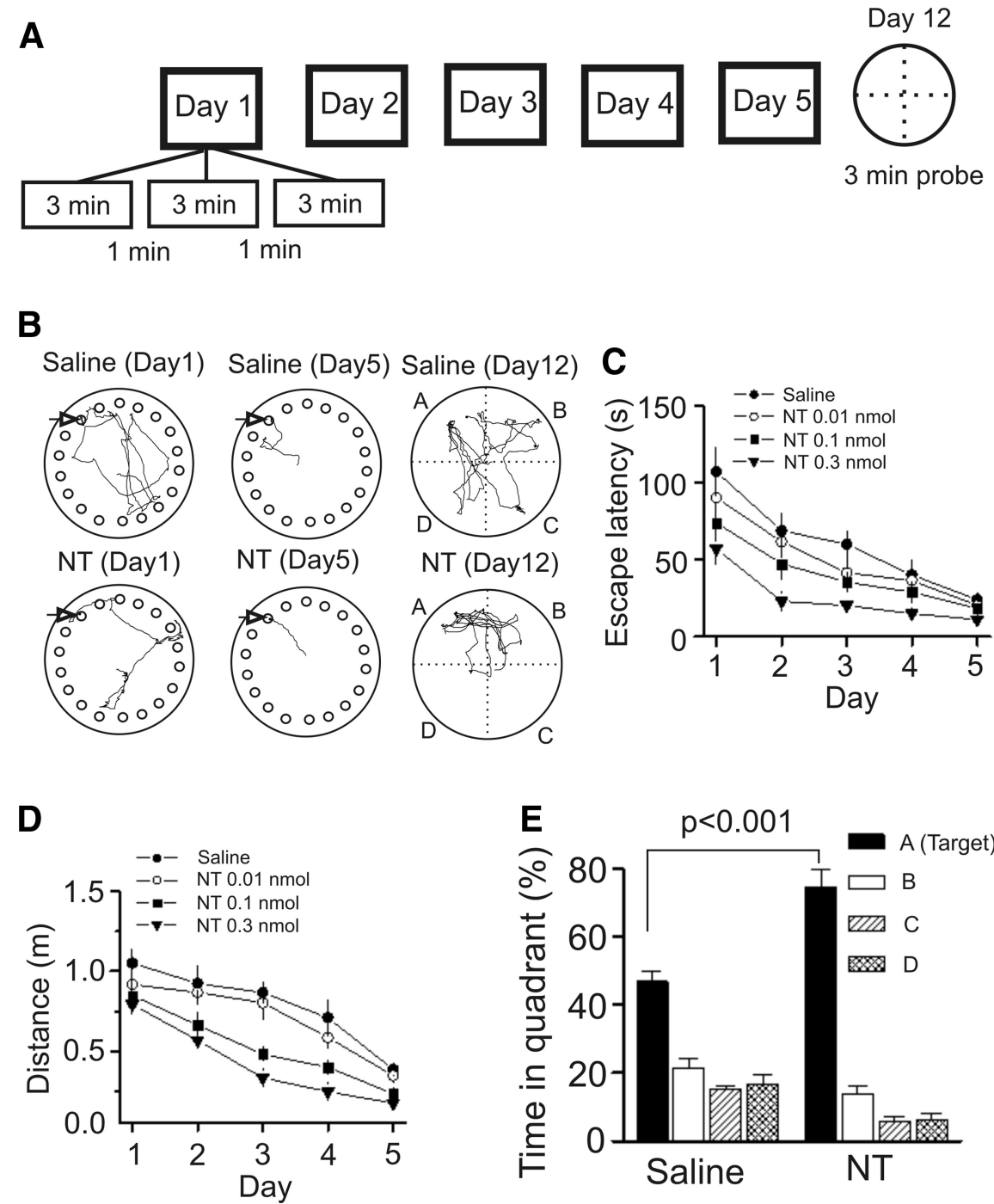

Figure 6. Microinjection of NT into the EC of rats dose-dependently increases spatial learning in the Barnes Maze Test. $\boldsymbol{A}$, Experimental protocol used to measure spatial learning and memory of rats in the Barnes Maze Test. The protocol consisted of 5 day trial of day 1 and day 5 and probe trials on day 12 in rats microinjected with saline $(0.9 \% \mathrm{NaCl})$ and $\mathrm{NT}(0.3 \mathrm{nmol})$. Arrow indicates the target hole. $C$, Mean latencies to the target hole were presented by groups. Rats were microinjected with saline and NT at doses of $0.01,0.1$, and $0.3 \mathrm{nmol}$. $\boldsymbol{D}$, Mean distances traveled were presented in groups. $\boldsymbol{E}$, Probe trial performance of the groups of rats injected with saline and NT $(0.3 \mathrm{nmol})$ as presented by the proportion of total time spent in each quadrant.

(latency: $F_{(1,13)}=9.92, p=0.008$; Fig. $8 B_{1}$; distance: $F_{(1,13)}=$ 14.63, $p=0.002$; Figure $\left.8 B_{2}\right)$. Likewise, the percentage of time spent in the target quadrant in TREK-2 KO mice injected with NT was not significantly different from that of TREK-2 KO mice injected with saline, whereas the WT mice injected with NT spent more time in the target quadrant than those injected with saline (Fig. $8 B_{3}$ ). These data together indicate that TREK-2 channels are required for NT-mediated enhancement of spatial learning. Furthermore, compared with WT mice injected with saline, TREK-2 $\mathrm{KO}$ mice injected with saline failed to show significant differences in latency $\left(F_{(1,13)}=0.0003, p=0.98\right.$; Fig. $\left.8 B_{1}\right)$, distance traveled $\left(F_{(1,13)}=2.6, p=0.131\right.$; Fig. $\left.8 B_{2}\right)$, and time spent in the target quadrant measured at day $12\left(p=0.4\right.$; Fig. $\left.8 B_{3}\right)$.

\section{Activation of NTS1 increases neuronal excitability and facilitates spatial memory in a mouse model of $\mathrm{AD}$}

We then performed experiments by using APP/PS1 mice, a mouse model of AD (Garcia-Alloza et al., 2006). We have shown 
A
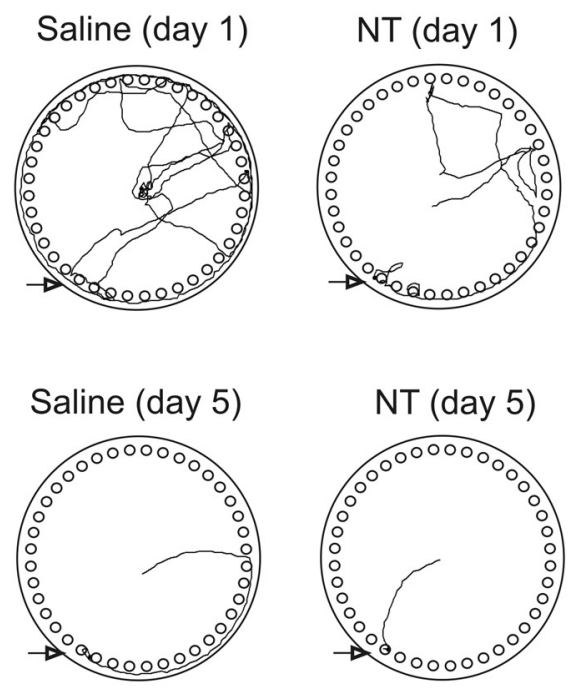

$\mathrm{B}_{1}$

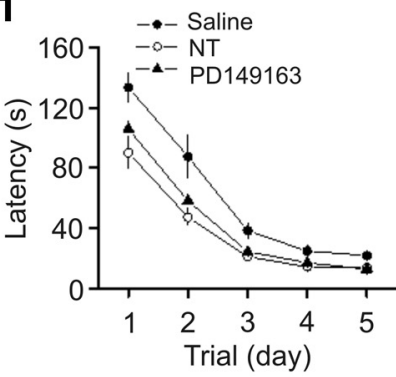

$\mathrm{B}_{2}$

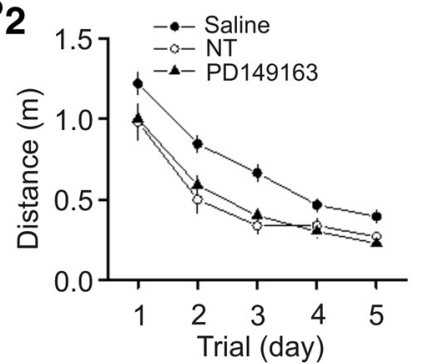

$\mathrm{B}_{3}$
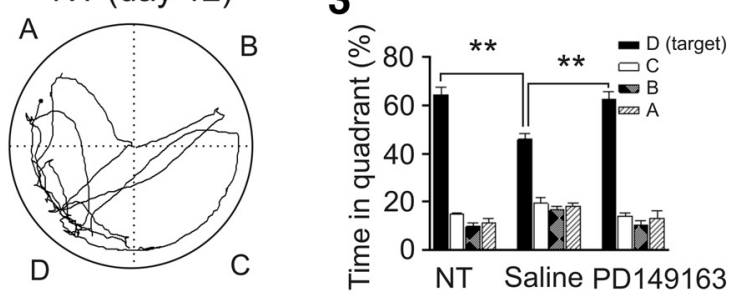

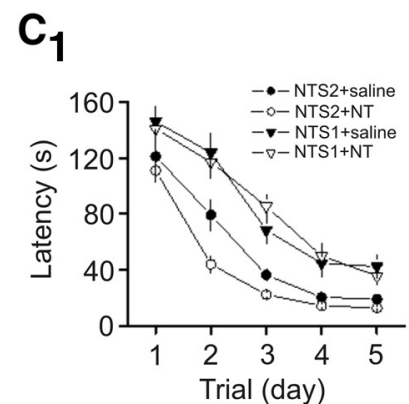

$\mathbf{C}_{2}$

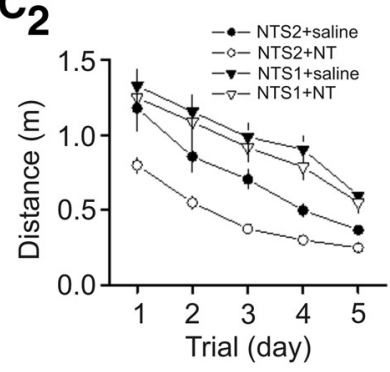

$\mathrm{C}_{3}$

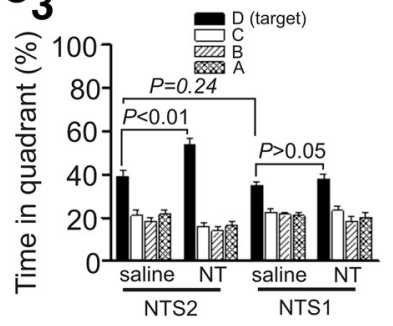

Figure 7. NT facilitates spatial learning by activation of NTS1 receptors. $\boldsymbol{A}, \boldsymbol{B}$, Microinjection of NT and the small-molecule NTS1 agonist (PD149163) into the EC of WT mice facilitated spatial learning and memory. $\boldsymbol{A}$, Representative traces from the last trial of day 1 and day 5 and the probe trial in mice bilaterally microinjected with saline and NT $(0.3 \mathrm{nmol}, 0.5 \mu \mathrm{l} / \mathrm{side}) . \boldsymbol{B}_{1}$, Mean latencies to the target hole. $\boldsymbol{B}_{2}$, Mean distances traveled. $\boldsymbol{B}_{3}$, Probe trial performance as presented by the proportion of total time spent in each quadrant. ${ }^{* *} p<0.01$. $\boldsymbol{C}_{\mathbf{1}}-\boldsymbol{C}_{3}$, Microinjection of NT into the EC of NTS1 K0 mice failed to facilitate spatial learning, whereas NT still increased spatial learning in NTS2 K0 mice. $C_{1}$, Mean latencies in NTS1 or NTS2 K0 mice bilaterally injected with saline or NT (0.3 $\mathrm{nmol}, 0.5 \mu \mathrm{l} / \mathrm{side}) . \boldsymbol{C}_{2}$, Mean distances traveled in NTS1 or NTS2 $\mathrm{KO}$ mice injected with saline or NT $(0.3 \mathrm{nmol}, 0.5 \mu \mathrm{l} / \mathrm{side}) . \boldsymbol{C}_{3}$, Percentage of the time spent in each quadrant in NTS1 or NTS2 $\mathrm{K} 0$ mice injected with saline or NT $(0.3 \mathrm{nmol}, 0.5 \mu \mathrm{l} / \mathrm{side})$.

previously that these mice exhibited plaques when they were older than 6 months (Dhawan and Combs, 2012). We therefore used the APP/PS1 mice at the age of 8-10 months. We first tested the effects of NT on AP firing recorded from layer II stellate neurons in the EC. The RMPs recorded from layer II stellate neurons in slices cut from APP/PS1 mice $(-59.7 \pm 0.7 \mathrm{mV}, n=$ 11 cells from 4 mice) were not significantly different from those of WT mice $(-60.2 \pm 0.5 \mathrm{mV}, n=12$ cells from 4 mice; data not shown). Bath application of NT $(0.25 \mu \mathrm{M})$ robustly increased the firing frequency of APs recorded from stellate neurons in slices cut from APP/PS1 mice ( $4.7 \pm 0.8$-fold increase, $n=11$ cells from 4 mice, $p<0.001$; Fig. $9 A$ ). NT-induced facilitation of AP firing frequency recorded from APP/PS1 mice was not significantly different from that recorded from the age-matched WT mice $(5.3 \pm 1.2$-fold increase, $n=12$ cells from 4 mice, $p=0.55$; Fig. 9A). Furthermore, bath application of NTS1 agonist PD149163 $(0.25 \mu \mathrm{M})$ also vigorously facilitated AP firing frequency in APP/PS1 mice ( $5.6 \pm 1.2$-fold increase, $n=14$ cells from 4 mice, $p<0.001$; Fig. $9 A$ ). These data together demonstrate that activation of NTS1 also increases neuronal excitability in APP/PS1 mice. We then compared the spatial learning and memory ability of APP/PS1 mice with the WT mice using the Barnes Maze Test. Compared with the age-matched WT mice, APP/PS1 mice exhibited significantly enhanced latency $\left(F_{(1,15)}=\right.$
15.39, $p=0.001$; Fig. $\left.9 B_{1}\right)$, lengthened travel distance $\left(F_{(1,15)}=\right.$ $6.42, p=0.023$; Fig. $\left.9 B_{2}\right)$, and decreased percentage of the time spent in the target quadrant $\left(p=0.02\right.$; Fig. $\left.9 B_{3}\right)$. These results indicate that APP/PS1 mice showed impaired cognitive functions. We further tested the effects of PD149163 on spatial learning and memory in APP/PS1 mice. Bilateral microinjection of PD149163 (0.3 nmol) significantly reduced the escape latency $\left(F_{(1,14)}=28.89, p<0.0001\right.$; Fig. $\left.9 B_{1}\right)$ and the distance traveled $\left(F_{(1,14)}=23.47, p<0.001\right.$; Fig. $\left.9 B_{2}\right)$ but significantly increased the percentage of time spent in the target quadrant (Fig. 9 $B_{3}$ ) demonstrating that PD149163 improves spatial learning and memory in APP/PS1 mice.

\section{Discussion}

Our results demonstrate that activation of NTS1 receptors in the EC generates persistent increases in neuronal excitability. NTinduced increases in neuronal excitability are mediated by phosphorylation and inhibition of TREK-2 channels and require the functions of G-proteins, PLC and PKC. Activation of NTS1 facilitates spatial learning and memory via PKC-dependent downregulation of TREK-2 channels, suggesting that NT-induced facilitation of neuronal excitability is a novel cellular and molecular substrate for learning and memory. Furthermore, applications of NT and NTS1 agonist, PD149163, also increase AP firing 
in slices cut from APP/PS1 mice and microinjection of PD149163 into the EC of APP/PS1 mice significantly increased the spatial learning and memory of these mice, suggesting that NTS1 agonists exert beneficial effects at least on $\mathrm{AD}$ animal models.

Ionic mechanisms underlying NTS1mediated increase in neuronal excitability and facilitation of spatial learning

Application of NT increases neuronal excitability by depolarizing entorhinal neurons suggesting that activation of NTS1 receptors modifies the movement of ions across the membrane, which is usually conducted by ion channels or transporters. NT has been shown to inhibit $\mathrm{Na}^{+} / \mathrm{K}^{+}$pump (López Ordieres and Rodríguez de Lores Arnaiz, 2000). The $\mathrm{Na}^{+} / \mathrm{K}^{+}$pump creates a concentration gradient by moving $3 \mathrm{Na}^{+}$out and $2 \mathrm{~K}^{+}$ into cells and inhibition of this pump, thereby, should create a net accumulation of positive ions inside cells leading to depolarization. Extracellular $\mathrm{K}^{+}$is a requisite for the function of the $\mathrm{Na}^{+} / \mathrm{K}^{+}$ pump. Our result that removal of extracellular $\mathrm{K}^{+}$did not block but significantly increased NT-induced inward HCs demonstrates that NT increases neuronal excitability unlikely by inhibition of $\mathrm{Na}^{+} / \mathrm{K}^{+}$pump. One explanation for NTinduced higher level of inward HCs in the absence of extracellular $\mathrm{K}^{+}$is that depletion of extracellular $\mathrm{K}^{+}$increases the driving force for $\mathrm{K}^{+}$efflux via $\mathrm{K}^{+}$channels leading to stronger inhibition of $\mathrm{K}^{+}$channels by NT.

Our results demonstrate that NT facilitates neuronal excitability by inhibition of background $\mathrm{K}^{+}$channels based on the following lines of evidence. First, NT significantly increased the input resistance, suggesting that NT inhibits a membrane conductance. Second, replacing intracellular $\mathrm{K}^{+}$with $\mathrm{Cs}^{+}$blocked NT-induced inward HCs. Third, the reversal potential of NT-induced currents had a reversal potential close to the $\mathrm{K}^{+}$ reversal potential. Nonetheless, the involved $\mathrm{K}^{+}$channels are unlikely to be the inwardly rectifier $\mathrm{K}^{+}$channels because the I-V curve of NT-sensitive currents did not show inward rectification, but a little outward rectification and application of the inward rectifier $\mathrm{K}^{+}$channel blocker tertiapin-Q failed to significantly alter NT-induced inward HCs. Moreover, SCH23390 is an antagonist of $\mathrm{D}_{1}$-like receptors as well as a blocker for inward rectifier $\mathrm{K}^{+}$channels (Kuzhikandathil and Oxford, 2002). Our result that application of SCH23390 failed to alter NT-induced facilitation of AP firing frequency (Fig. $1 F$ ) further excludes the participation of inward rectifier $\mathrm{K}^{+}$channels. The results that NT-induced inward HCs were insensitive to the classical $\mathrm{K}^{+}$channel blockers, such as TEA, 4-AP, and extracellular $\mathrm{Cs}^{+}$, suggest that NT inhib-
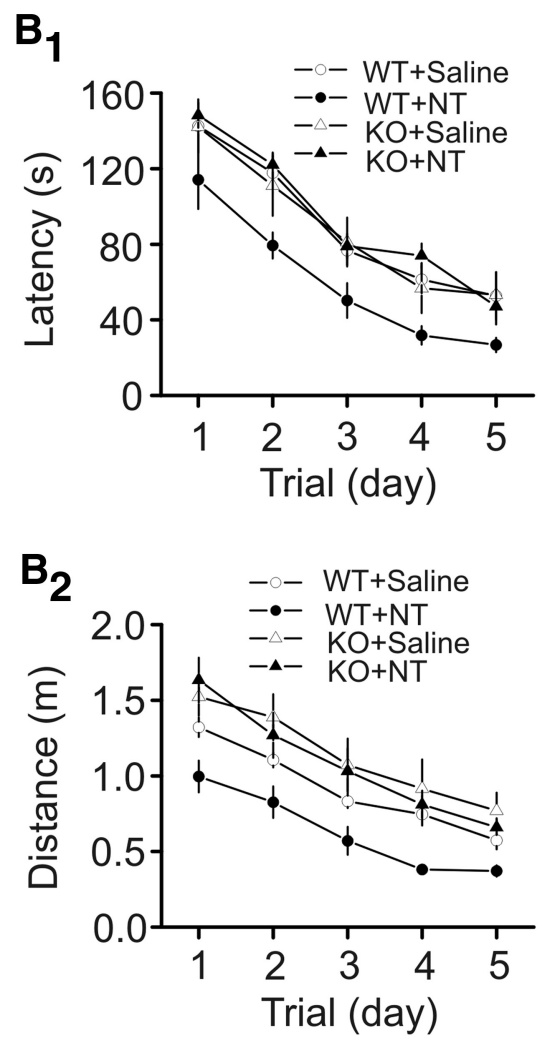

$\mathrm{B}_{3}$

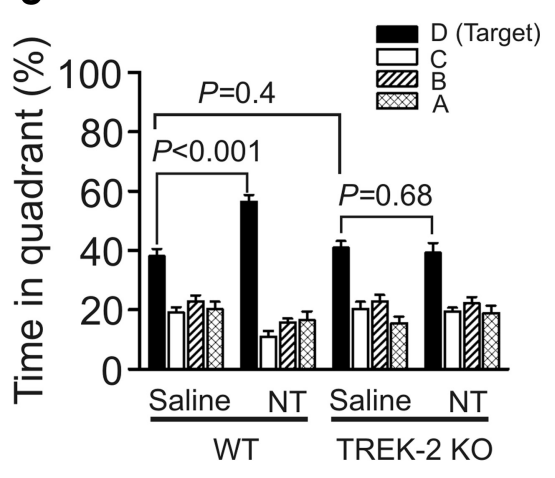

Figure 8. NT-mediated facilitation of spatial learning requires the functions of PKC and TREK-2 channels. $A_{1}-A_{3}$, Microinjection of the PKC inhibitor GF109203X ( 50 pmol) into the EC significantly reduced the effects of NT on escape latency $\left(\boldsymbol{A}_{\boldsymbol{1}}\right)$, travel distance KO mice failed to significantly alter escape latency $\left(\boldsymbol{B}_{1}\right)$, travel distance $\left(\boldsymbol{B}_{2}\right)$, and the percentage of time spent in the target quadrant in probe trial $\left(\boldsymbol{B}_{3}\right)$, whereas the effects of NT were still observed in WT mice.

its $\mathrm{K}_{2 \mathrm{P}}$ channels. NT has been reported to inhibit a type of $\mathrm{K}_{2 \mathrm{P}}$ channels (possibly TRESK and/or TASK-3) in spinal cord neurons (Kadiri et al., 2011). However, the channels inhibited by NT in the spinal cord neurons are sensitive to both $\mathrm{Ba}^{2+}$ and $\mathrm{Zn}^{2+}$ (Kadiri et al., 2011), which is in contrast to our results that NTinduced inward HCs in the EC were sensitive to $\mathrm{Ba}^{2+}$ but insensitive to $\mathrm{Zn}^{2+}$. These results suggest that NT inhibits a different type of $\mathrm{K}_{2 \mathrm{P}}$ channels in the EC. We provide further evidence demonstrating that NT increases neuronal excitability by inhibition of TREK-2 channels. Application of NT failed to increase the AP firing frequency in slices cut from TREK-2 KO mice, whereas application of NT still robustly increased AP firing frequency in slices cut from WT mice. Bath application of NT to HEK293 cells coexpressing NTS1 and TREK-2 channels induced an inward 
A
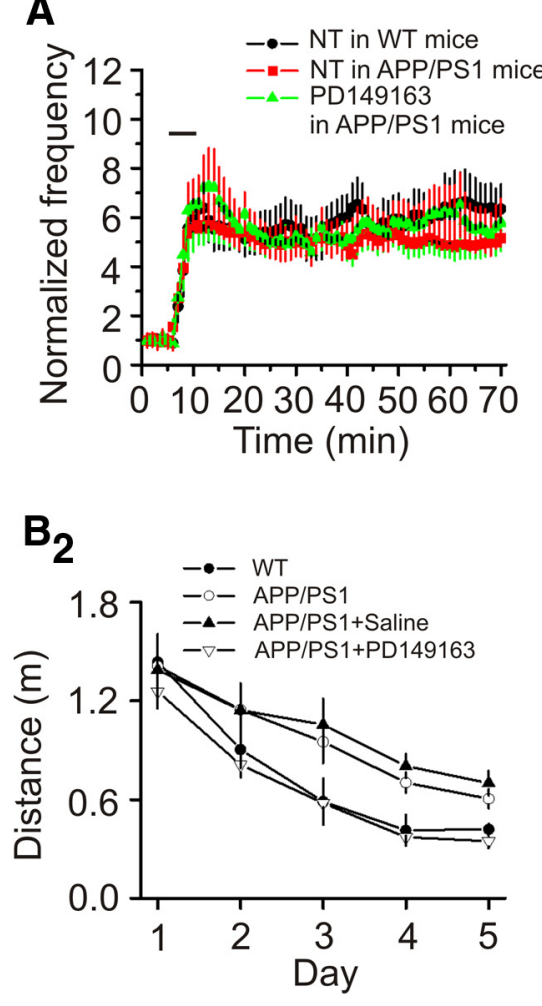
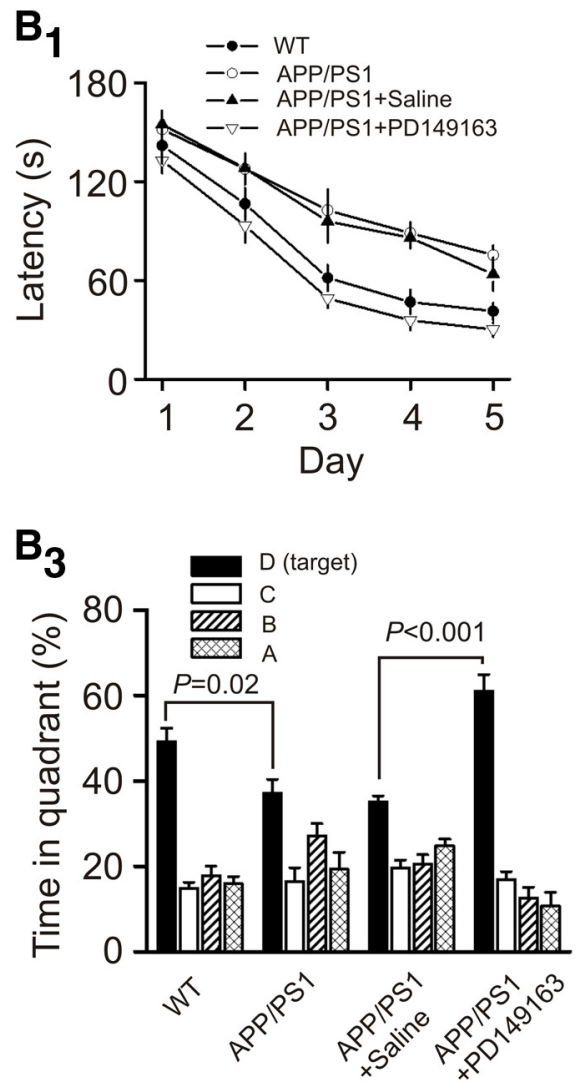

Figure 9. Activation of NTS1 increases neuronal excitability and improves the memory status of APP/PS1 mice. $\boldsymbol{A}$, Bath application of NT (red) and PD149163 (green) increased the firing frequency of APs recorded from layer II stellate neurons of the EC in slices cut from APP/PS1 mice and age-matched WT mice (black). $\boldsymbol{B}_{\boldsymbol{1}}-\boldsymbol{B}_{3}$, Bilateral microinjection of PD149163 at 0.3 nmol into the EC of APP/PS1 mice significantly reduced the latency $\left(\boldsymbol{B}_{1}\right)$ and the distance traveled $\left(\boldsymbol{B}_{2}\right)$ but increased the percentage of time spent in the target quadrant $\left(\boldsymbol{B}_{3}\right)$ compared with the APP/PS1 mice microinjected with saline $(0.9 \% \mathrm{NaCl})$ in the same fashion. APP/PS1 mice showed lengthened escape latency $\left(\boldsymbol{B}_{1}\right)$ and travel distance $\left(\boldsymbol{B}_{2}\right)$ but decreased percentage of time spent in the target quadrant $\left(\boldsymbol{B}_{\mathbf{3}}\right)$ compared with the age-matched WT mice.

HC, whereas NT failed to modify the HCs in HEK293 cells transfected with either NTS1 receptors or TREK-2 channels alone. These results together indicate that NT inhibits TREK-2 channels to increase the excitability of entorhinal neurons.

Although we have demonstrated that NT-induced facilitation of neuronal excitability is unlikely because of its indirect effects on the releases of glutamate, GABA, DA, and Ach, the potential indirect contributions of other factors, such as the serotoninergic, purinergic, glycinergic, and other peptidergic systems, have not been examined. However, it seems less likely that the effects of NT would be related to serotonin or glycine because both serotonin (Lei, 2012) and glycine (Breustedt et al., 2004) inhibit neuronal excitability in the EC. The potential interaction between NT and other neurotransmitters still needs further investigation.

Signaling mechanisms underlying NTS1-induced facilitation of neuronal excitability and augmentation of spatial learning in the EC

Whereas NT interacts with NTS1, NTS2, and NTS3 receptors, our results demonstrate that NT increases neuronal excitability and facilitates spatial learning via activation of NTS1 receptors based on the results from both pharmacological experiments and KO mice. Activation of NTS1 increases the activity of PLC leading to elevation of intracellular $\mathrm{Ca}^{2+}$ release and activation of PKC. Our results demonstrate that NT-induced facilitation of neuronal excitability is related to intracellular $\mathrm{Ca}^{2+}$ level because intra- cellular application of BAPTA attenuated the effects of NT. However, blockade of intracellular $\mathrm{Ca}^{2+}$ release or depletion of extracellular $\mathrm{Ca}^{2+}$ failed to alter significantly NT-mediated facilitation of neuronal excitability. Different from NTinduced facilitation of neuronal excitability, $\mathrm{Ca}^{2+}$ influx via nonspecific cation and $\mathrm{L}$-type $\mathrm{Ca}^{2+}$ channels is required for the persistent firing induced by brief depolarization in layer $\mathrm{V}$ entorhinal neurons (Egorov et al., 2002). One plausible explanation for the role of $\mathrm{Ca}^{2+}$ in NT-induced facilitation of neuronal excitability is that intracellular $\mathrm{Ca}^{2+}$ is required for the activation of $\mathrm{Ca}^{2+}$-dependent intracellular signals. Indeed, our results demonstrate that $\mathrm{PKC}$, possibly $\mathrm{Ca}^{2+}$-dependent PKC, is necessary for NT-induced facilitation of neuronal excitability. We further demonstrate that NT induces persistent phosphorylation of TREK-2 channels. In HEK293 cells coexpressing NTS1 and the TREK-2 mutant in which serine 326 and serine 359 were mutated to alanine, NT failed to induce an inward HC, suggesting that PKC phosphorylates TREK-2 channels on these two sites. Consistent with our results, PKC-dependent phosphorylation of TREK-2 channels on these two amino acids by activation of muscarinic receptors (Kang et al., 2006) and AMPactivated protein kinase (Kréneisz et al., 2009) also results in inhibition of TREK-2 channels. PKC-dependent phosphorylation and inhibition of TREK-2 channels likely contribute to NT-mediated facilitation of spatial learning because inhibition of PKC or deletion of TREK-2 gene nullified the facilitatory effects of NT on spatial learning. However, the specific PKC isoforms involved in NTmediated facilitation of neuronal excitability and spatial learning still await further investigation. In line with our results, it is well established that both PKC (Bonini et al., 2007; Dash et al., 2007; Sun and Alkon, 2010) and TREK-2 channels (Pan et al., 2003; Huang and Yu, 2008; Deng et al., 2009) are substrates of learning and memory.

Whereas our results demonstrate that both NTS1 and TREK-2 channels are required for NT-induced facilitation of spatial learning, the roles of NTS1 and TREK-2 channels in the modulation of spatial learning by endogenously released NT are still elusive. NTS1 KO mice showed increased escape latency and travel distance, suggesting that NTS1 activated by endogenously released NT is involved in the processes of spatial learning. However, the percentage of time spent in the target quadrant in the probe test measured on day 12 was not altered in NTS1 KO mice, suggesting that NTS1 may play a less important role in memory retention. Moreover, TREK-2 KO mice showed no differences in spatial learning and memory, although acute microinjection of NT into the EC of TREK-2 KO mice failed to facilitate spatial learning and memory, demonstrating a role of TREK-2 channels in exogenously applied NT. One explanation for the discrepancy of these results is that the roles of TREK-2 channels may be replaced by other $\mathrm{K}_{2 \mathrm{P}}$ channels in TREK- $2 \mathrm{KO}$ mice because the 
electrophysiological properties, such as the RMPs, were not changed in these mice. Evidence supporting this possibility comes from the observations that the RMPs of neurons in TREK-1 (Heurteaux et al., 2004) or TASK-1 (Aller et al., 2005) KO mice were not changed either. Moreover, although our results demonstrate that TREK-2 channel is the major target of NTS1 receptors, the possibility that an alternative target for endogenously released NT has been developed in TREK-2 KO mice cannot be excluded.

\section{Significance of NTS1-induced enhancement of neuronal excitability and spatial learning in AD}

There is increasing evidence demonstrating that the functions of NT are closely associated with the memory status of both animals and humans. For example, in healthy adult humans, NTS1 polymorphisms are closely associated with variance in the performance of working memory (Li et al., 2011). NT binding sites are varied as a function of age and cognitive status with decreased NT binding sites in the brains of aged and cognitively impaired rats (Rowe et al., 2006). Application of NT or NT receptor agonists improves memory (Azmi et al., 2006; Ohinata et al., 2007; László et al., 2010), whereas administration of NT receptor antagonists impairs cognitive processes (Tirado-Santiago et al., 2006). Whereas the effects of NT on memory are usually considered to be mediated by NTS1 (Azmi et al., 2006; Tirado-Santiago et al., 2006; Ohinata et al., 2007; László et al., 2010), reduced fear memory has also been observed in NTS2 KO mice (Yamauchi et al., 2007). Although these data generally support a role for NT in learning and memory, the cellular and molecular mechanisms whereby NT facilitates memory have not been determined. In the present study, we took the advantage that high density of NT receptors is expressed in the superficial layers of the EC, an indispensable structure involved in learning and memory. We first examined the effects of NT on neuronal excitability, and our results demonstrated that brief ( $5 \mathrm{~min}$ ) application of NT persistently increased the AP firing frequency. This phenomenon resembles the long-term potentiation. Whereas long-term potentiation is generally considered as a cellular and molecular substrate for learning and memory, the eventual outcome of long-term potentiation is to increase the excitability of the postsynaptic neurons. NT-induced persistent increase in neuronal excitability bypasses the processes of synaptic transmission and directly leads to increases in neuronal excitability. Thus, it is reasonable to speculate that NT-induced persistent increase in neuronal excitability may represent a novel cellular mechanism involved in learning and memory.

Memory impairment is a characteristic symptom observed in many diseases, such as AD. Up to date, there have been few effective drugs that can relieve the memory loss of these diseases. Grid cell firing correlates to forming an internal spatial map and is driven by the polymodal input to the EC that occurs as an animal explores its environment (Sargolini et al., 2006; Hafting et al., 2008; Brandon et al., 2011; Burgalossi et al., 2011). We propose that NT may increase the probability of grid cell firing in response to that input, which promotes a more active circuit in the encoding of information about one's environment. Our data clearly show that application of NT or NTS1 agonist PD149163 facilitates spatial learning. We further showed that microinjection of PD149163 into the EC of APP/PS1 mice also significantly improved the memory status of these mice, highlighting a therapeutic value of this type of drugs in AD. Therefore, one immediate implication of our results is that NTS1 agonists may have the potential to be developed as cognition-enhancing drugs to relieve the symptoms of $\mathrm{AD}$.

In conclusion, we found that activation of NTS1 receptors in the EC induces a persistent increase in AP firing and facilitates spatial learning. NT-induced facilitation of neuronal excitability and spatial learning require the functions of PLC and PKC and are mediated by phosphorylation and inhibition of TREK-2 channels. NT and NTS1 agonist PD149163 also induced persistent AP firing and facilitated spatial memory in APP/PS1 mice, suggesting that NT-mediated augmentation of learning and memory may have therapeutic potentials to relieve memory loss exhibited in $\mathrm{AD}$.

\section{References}

Aller MI, Veale EL, Linden AM, Sandu C, Schwaninger M, Evans LJ, Korpi ER, Mathie A, Wisden W, Brickley SG (2005) Modifying the subunit composition of TASK channels alters the modulation of a leak conductance in cerebellar granule neurons. J Neurosci 25:11455-11467. CrossRef Medline

Alonso A, Klink R (1993) Differential electroresponsiveness of stellate and pyramidal-like cells of medial entorhinal cortex layer II. J Neurophysiol 70:128-143. Medline

Atoji Y, Watanabe H, Yamamoto Y, Suzuki Y (1995) Distribution of neurotensin-containing neurons in the central nervous system of the dog. J Comp Neurol 353:67-88. CrossRef Medline

Azmi N, Norman C, Spicer CH, Bennett GW (2006) Effects of a neurotensin analogue (PD149163) and antagonist (SR142948A) on the scopolamineinduced deficits in a novel object discrimination task. Behav Pharmacol 17:357-362. CrossRef Medline

Bang H, Kim Y, Kim D (2000) TREK-2, a new member of the mechanosensitive tandem-pore $\mathrm{K}^{+}$channel family. J Biol Chem 275:17412-17419. Medline

Bayliss DA, Sirois JE, Talley EM (2003) The TASK family: two-pore domain background $\mathrm{K}^{+}$channels. Mol Interv 3:205-219. CrossRef Medline

Bonini JS, Da Silva WC, Bevilaqua LR, Medina JH, Izquierdo I, Cammarota M (2007) On the participation of hippocampal PKC in acquisition, consolidation and reconsolidation of spatial memory. Neuroscience 147:3745. CrossRef Medline

Bradford MM (1976) A rapid and sensitive method for the quantitation of microgram quantities of protein utilizing the principle of protein-dye binding. Anal Biochem 72:248-254. CrossRef Medline

Brandon MP, Bogaard AR, Libby CP, Connerney MA, Gupta K, Hasselmo ME (2011) Reduction of theta rhythm dissociates grid cell spatial periodicity from directional tuning. Science 332:595-599. CrossRef Medline

Breustedt J, Schmitz D, Heinemann U, Schmieden V (2004) Characterization of the inhibitory glycine receptor on entorhinal cortex neurons. Eur J Neurosci 19:1987-1991. CrossRef Medline

Burgalossi A, Herfst L, von Heimendahl M, Förste H, Haskic K, Schmidt M, Brecht M (2011) Microcircuits of functionally identified neurons in the rat medial entorhinal cortex. Neuron 70:773-786. CrossRef Medline

Canto CB, Wouterlood FG, Witter MP (2008) What does the anatomical organization of the entorhinal cortex tell us? Neural Plast 2008:381243. CrossRef Medline

Chen ST, Tsai MS, Shen CL (1988) Distribution of neurotensin-like immunoreactivity in the central nervous system of the Formosan monkey. Proc Natl Sci Counc Repub China B 12:163-173. Medline

Dash PK, Moore AN, Kobori N, Runyan JD (2007) Molecular activity underlying working memory. Learn Mem 14:554-563. CrossRef Medline

Deng PY, Lei S (2008) Serotonin increases GABA release in rat entorhinal cortex by inhibiting interneuron TASK- $3 \mathrm{~K}^{+}$channels. Mol Cell Neurosci 39:273-284. CrossRef Medline

Deng PY, Porter JE, Shin HS, Lei S (2006) Thyrotropin-releasing hormone increases GABA release in rat hippocampus. J Physiol 577:497-511. CrossRef Medline

Deng PY, Poudel SK, Rojanathammanee L, Porter JE, Lei S (2007) Serotonin inhibits neuronal excitability by activating two-pore domain $\mathrm{K}^{+}$ channels in the entorhinal cortex. Mol Pharmacol 72:208-218. CrossRef Medline

Deng PY, Xiao Z, Yang C, Rojanathammanee L, Grisanti L, Watt J, Geiger JD, Liu R, Porter JE, Lei S (2009) $\mathrm{GABA}_{\mathrm{B}}$ receptor activation inhibits neu- 
ronal excitability and spatial learning in the entorhinal cortex by activating TREK-2 $\mathrm{K}^{+}$channels. Neuron 63:230-243. CrossRef Medline

Deng PY, Xiao Z, Jha A, Ramonet D, Matsui T, Leitges M, Shin HS, Porter JE, Geiger JD, Lei S (2010) Cholecystokinin facilitates glutamate release by increasing the number of readily releasable vesicles and releasing probability. J Neurosci 30:5136-5148. CrossRef Medline

Dhawan G, Combs CK (2012) Inhibition of Src kinase activity attenuates amyloid associated microgliosis in a murine model of Alzheimer's disease. J Neuroinflammation 9:117. CrossRef Medline

Dickson CT, Mena AR, Alonso A (1997) Electroresponsiveness of medial entorhinal cortex layer III neurons in vitro. Neuroscience 81:937-950. CrossRef Medline

Dolcos F, LaBar KS, Cabeza R (2005) Remembering one year later: role of the amygdala and the medial temporal lobe memory system in retrieving emotional memories. Proc Natl Acad Sci U S A 102:2626-2631. CrossRef Medline

Egorov AV, Hamam BN, Fransén E, Hasselmo ME, Alonso AA (2002) Graded persistent activity in entorhinal cortex neurons. Nature 420:173178. CrossRef Medline

Faggin BM, Zubieta JK, Rezvani AH, Cubeddu LX (1990) Neurotensininduced dopamine release in vivo and in vitro from substantia nigra and nucleus caudate. J Pharmacol Exp Ther 252:817-825. Medline

Feifel D, Melendez G, Shilling PD (2004) Reversal of sensorimotor gating deficits in Brattleboro rats by acute administration of clozapine and a neurotensin agonist, but not haloperidol: a potential predictive model for novel antipsychotic effects. Neuropsychopharmacology 29:731-738. CrossRef Medline

Feifel D, Goldenberg J, Melendez G, Shilling PD (2010) The acute and subchronic effects of a brain-penetrating, neurotensin-1 receptor agonist on feeding, body weight and temperature. Neuropharmacology 58:195-198. CrossRef Medline

Fink M, Duprat F, Lesage F, Reyes R, Romey G, Heurteaux C, Lazdunski M (1996) Cloning, functional expression and brain localization of a novel unconventional outward rectifier $\mathrm{K}^{+}$channel. EMBO J 15:6854-6862. Medline

Garcia-Alloza M, Robbins EM, Zhang-Nunes SX, Purcell SM, Betensky RA, Raju S, Prada C, Greenberg SM, Bacskai BJ, Frosch MP (2006) Characterization of amyloid deposition in the APPswe/PS1dE9 mouse model of Alzheimer disease. Neurobiol Dis 24:516-524. CrossRef Medline

Glogauer M, Arora P, Chou D, Janmey PA, Downey GP, McCulloch CA (1998) The role of actin-binding protein 280 in integrin-dependent mechanoprotection. J Biol Chem 273:1689-1698. Medline

Gómez-Isla T, Price JL, McKeel DW Jr, Morris JC, Growdon JH, Hyman BT (1996) Profound loss of layer II entorhinal cortex neurons occurs in very mild Alzheimer's disease. J Neurosci 16:4491-4500. Medline

Gu W, Schlichthörl G, Hirsch JR, Engels H, Karschin C, Karschin A, Derst C, Steinlein OK, Daut J (2002) Expression pattern and functional characteristics of two novel splice variants of the two-pore-domain potassium channel TREK-2. J Physiol 539:657-668. CrossRef Medline

Guyon A, Tardy MP, Rovère C, Nahon JL, Barhanin J, Lesage F (2009) Glucose inhibition persists in hypothalamic neurons lacking tandem-pore $\mathrm{K}^{+}$channels. J Neurosci 29:2528-2533. CrossRef Medline

Hafting T, Fyhn M, Bonnevie T, Moser MB, Moser EI (2008) Hippocampusindependent phase precession in entorhinal grid cells. Nature 453:12481252. CrossRef Medline

Hamid EH, Hyde TM, Egan MF, Wolf SS, Herman MM, Nemeroff CB, Kleinman JE (2002) Neurotensin receptor binding abnormalities in the entorhinal cortex in schizophrenia and affective disorders. Biol Psychiatry 51:795-800. CrossRef Medline

Han J, Truell J, Gnatenco C, Kim D (2002) Characterization of four types of background potassium channels in rat cerebellar granule neurons. J Physiol 542:431-444. CrossRef Medline

Hermans E, Maloteaux JM (1998) Mechanisms of regulation of neurotensin receptors. Pharmacol Ther 79:89-104. CrossRef Medline

Heurteaux C, Guy N, Laigle C, Blondeau N, Duprat F, Mazzuca M, LangLazdunski L, Widmann C, Zanzouri M, Romey G, Lazdunski M (2004) TREK-1, a $\mathrm{K}^{+}$channel involved in neuroprotection and general anesthesia. EMBO J 23:2684-2695. CrossRef Medline

Hu HJ, Gereau RW 4th (2003) ERK integrates PKA and PKC signaling in superficial dorsal horn neurons: II. Modulation of neuronal excitability. J Neurophysiol 90:1680-1688. CrossRef Medline

Huang D, Yu B (2008) Recent advance and possible future in TREK-2: a two-pore potassium channel may involved in the process of NPP, brain ischemia and memory impairment. Med Hypotheses 70:618-624. CrossRef Medline

Hyman BT, Van Hoesen GW, Damasio AR, Barnes CL (1984) Alzheimer's disease: cell-specific pathology isolates the hippocampal formation. Science 225:1168-1170. CrossRef Medline

Kadiri N, Rodeau JL, Schlichter R, Hugel S (2011) Neurotensin inhibits background $\mathrm{K}^{+}$channels and facilitates glutamatergic transmission in rat spinal cord dorsal horn. Eur J Neurosci 34:1230-1240. CrossRef Medline

Kang D, Mariash E, Kim D (2004) Functional expression of TRESK-2, a new member of the tandem-pore $\mathrm{K}^{+}$channel family. J Biol Chem 279:2806328070. CrossRef Medline

Kang D, Han J, Kim D (2006) Mechanism of inhibition of TREK-2 (K2P10.1) by the Gq-coupled M3 muscarinic receptor. Am J Physiol Cell Physiol 291:C649-C656. CrossRef Medline

Kim Y, Bang H, Kim D (2000) TASK-3, a new member of the tandem pore $\mathrm{K}^{+}$channel family. J Biol Chem 275:9340-9347. CrossRef Medline

Kotzbauer PT, Trojanowsk JQ, Lee VM (2001) Lewy body pathology in Alzheimer's disease. J Mol Neurosci 17:225-232. CrossRef Medline

Kréneisz O, Benoit JP, Bayliss DA, Mulkey DK (2009) AMP-activated protein kinase inhibits TREK channels. J Physiol 587:5819-5830. CrossRef Medline

Kuzhikandathil EV, Oxford GS (2002) Classic D1 dopamine receptor antagonist R-(+)-7-chloro-8-hydroxy-3-methyl-1-phenyl-2,3,4,5-tetrahydro-1H-3-benzazepine hydrochloride (SCH23390) directly inhibits G protein-coupled inwardly rectifying potassium channels. Mol Pharmacol 62:119-126. CrossRef Medline

Lahti RA, Cochrane EV, Roberts RC, Conley RR, Tamminga CA (1998) $\left[{ }^{3} \mathrm{H}\right]$ Neurotensin receptor densities in human postmortem brain tissue obtained from normal and schizophrenic persons: an autoradiographic study. J Neural Transm 105:507-516. CrossRef Medline

Lapchak PA, Araujo DM, Quirion R, Beaudet A (1990) Neurotensin regulation of endogenous acetylcholine release from rat cerebral cortex: effect of quinolinic acid lesions of the basal forebrain. J Neurochem 55:13971403. CrossRef Medline

Lapchak PA, Araujo DM, Quirion R, Beaudet A (1991) Neurotensin regulation of endogenous acetylcholine release from rat striatal slices is independent of dopaminergic tone. J Neurochem 56:651-657. CrossRef Medline

László K, Tóth K, Kertes E, Péczely L, Ollmann T, Lénárd L (2010) Effects of neurotensin in amygdaloid spatial learning mechanisms. Behav Brain Res 210:280-283. CrossRef Medline

Lei S (2012) Serotonergic modulation of neural activities in the entorhinal cortex. Int J Physiol Pathophysiol Pharmacol 4:201-210. Medline

Lei S, Deng PY, Porter JE, Shin HS (2007) Adrenergic facilitation of GABAergic transmission in rat entorhinal cortex. J Neurophysiol 98:2868-2877. CrossRef Medline

Lesage F (2003) Pharmacology of neuronal background potassium channels. Neuropharmacology 44:1-7. CrossRef Medline

Lesage F, Lazdunski M (2000) Molecular and functional properties of twopore-domain potassium channels. Am J Physiol Renal Physiol 279:F793F801. Medline

Lesage F, Guillemare E, Fink M, Duprat F, Lazdunski M, Romey G, Barhanin J (1996) TWIK-1, a ubiquitous human weakly inward rectifying $\mathrm{K}^{+}$ channel with a novel structure. EMBO J 15:1004-1011. Medline

Li J, Chen C, Chen C, He Q, Li H, Li J, Moyzis RK, Xue G, Dong Q (2011) Neurotensin receptor 1 gene (NTSR1) polymorphism is associated with working memory. PLoS One 6:e17365. CrossRef Medline

López Ordieres MG, Rodríguez de Lores Arnaiz G (2000) Neurotensin inhibits neuronal $\mathrm{Na}^{+}, \mathrm{K}^{+}$-ATPase activity through high affinity peptide receptor. Peptides 21:571-576. CrossRef Medline

Ma XY, Yu JM, Zhang SZ, Liu XY, Wu BH, Wei XL, Yan JQ, Sun HL, Yan HT, Zheng JQ (2011) External $\mathrm{Ba}^{2+}$ block of the two-pore domain potassium channel TREK-1 defines conformational transition in its selectivity filter. J Biol Chem 286:39813-39822. CrossRef Medline

Maeno H, Yamada K, Santo-Yamada Y, Aoki K, Sun YJ, Sato E, Fukushima T, Ogura H, Araki T, Kamichi S, Kimura I, Yamano M, Maeno-Hikichi Y, Watase K, Aoki S, Kiyama H, Wada E, Wada K (2004) Comparison of mice deficient in the high- or low-affinity neurotensin receptors, Ntsr 1 or $\mathrm{Ntsr} 2$, reveals a novel function for Ntsr2 in thermal nociception. Brain Res 998:122-129. CrossRef Medline

Martorana A, Martella G, D’Angelo V, Fusco FR, Spadoni F, Bernardi G, 
Stefani A (2006) Neurotensin effects on N-type calcium currents among rat pallidal neurons: an electrophysiological and immunohistochemical study. Synapse 60:371-383. CrossRef Medline

Nishimura R, Kato Y, Chen D, Harris SE, Mundy GR, Yoneda T (1998) Smad5 and DPC4 are key molecules in mediating BMP-2-induced osteoblastic differentiation of the pluripotent mesenchymal precursor cell line C2C12. J Biol Chem 273:1872-1879. CrossRef Medline

O'Connor WT, Tanganelli S, Ungerstedt U, Fuxe K (1992) The effects of neurotensin on GABA and acetylcholine release in the dorsal striatum of the rat: an in vivo microdialysis study. Brain Res 573:209-216. CrossRef Medline

Ohinata K, Sonoda S, Inoue N, Yamauchi R, Wada K, Yoshikawa M (2007) $\beta$-Lactotensin, a neurotensin agonist peptide derived from bovine $\beta$-lactoglobulin, enhances memory consolidation in mice. Peptides 28: 1470-1474. CrossRef Medline

Pan YP, Xu XH, Wang XL (2003) [mRNA expression alteration of two-pore potassium channels in the brain of beta-amyloid peptide25-35-induced memory impaired rats]. Yao Xue Xue Bao 38:721-724. Medline

Pepeu G, Giovannini MG (2009) Cholinesterase inhibitors and beyond. Curr Alzheimer Res 6:86-96. CrossRef Medline

Petkova-Kirova P, Rakovska A, Della Corte L, Zaekova G, Radomirov R, Mayer A (2008) Neurotensin modulation of acetylcholine, GABA, and aspartate release from rat prefrontal cortex studied in vivo with microdialysis. Brain Res Bull 77:129-135. CrossRef Medline

Rakovska A, Giovannini MG, Della Corte L, Kalfin R, Bianchi L, Pepeu G (1998) Neurotensin modulation of acetylcholine and GABA release from the rat hippocampus: an in vivo microdialysis study. Neurochem Int 33: 335-340. CrossRef Medline

Ramanathan G, Cilz NI, Kurada L, Hu B, Wang X, Lei S (2012) Vasopressin facilitates GABAergic transmission in rat hippocampus via activation of $\mathrm{V}_{1 \mathrm{~A}}$ receptors. Neuropharmacology 63:1218-1226. CrossRef Medline

Reyneke L, Russell VA, Taljaard JJ (1992) Regional effects of neurotensin on the electrically stimulated release of $\left[{ }^{3} \mathrm{H}\right]$ dopamine and $\left[{ }^{14} \mathrm{C}\right]$ acetylcholine in the rat nucleus accumbens. Neurochem Res 17:1143-1146. CrossRef Medline

Rowe WB, Kar S, Meaney MJ, Quirion R (2006) Neurotensin receptor levels as a function of brain aging and cognitive performance in the Morris water maze task in the rat. Peptides 27:2415-2423. CrossRef Medline

Sano Y, Inamura K, Miyake A, Mochizuki S, Kitada C, Yokoi H, Nozawa K, Okada H, Matsushime H, Furuichi K (2003) A novel two-pore domain $\mathrm{K}^{+}$channel, TRESK, is localized in the spinal cord. J Biol Chem 278: 27406-27412. CrossRef Medline

Sargolini F, Fyhn M, Hafting T, McNaughton BL, Witter MP, Moser MB, Moser EI (2006) Conjunctive representation of position, direction, and velocity in entorhinal cortex. Science 312:758-762. CrossRef Medline

Steffenach HA, Witter M, Moser MB, Moser EI (2005) Spatial memory in the rat requires the dorsolateral band of the entorhinal cortex. Neuron 45:301-313. CrossRef Medline

St-Gelais F, Jomphe C, Trudeau LE (2006) The role of neurotensin in central nervous system pathophysiology: what is the evidence? J Psychiatry Neurosci 31:229-245. Medline

Sun MK, Alkon DL (2010) Pharmacology of protein kinase C activators: cognition-enhancing and antidementic therapeutics. Pharmacol Ther 127:66-77. CrossRef Medline

Tirado-Santiago G, Lázaro-Muñoz G, Rodríguez-González V, MaldonadoVlaar CS (2006) Microinfusions of neurotensin antagonist SR 48692 within the nucleus accumbens core impair spatial learning in rats. Behav Neurosci 120:1093-1102. CrossRef Medline

van Marum RJ (2008) Current and future therapy in Alzheimer's disease. Fundam Clin Pharmacol 22:265-274. CrossRef Medline

Vincent JP, Mazella J, Kitabgi P (1999) Neurotensin and neurotensin receptors. Trends Pharmacol Sci 20:302-309. CrossRef Medline

Wang S, Zhang AP, Kurada L, Matsui T, Lei S (2011) Cholecystokinin facilitates neuronal excitability in the entorhinal cortex via activation of TRPC-like channels. J Neurophysiol 106:1515-1524. CrossRef Medline

Wang S, Chen X, Kurada L, Huang Z, Lei S (2012) Activation of group II metabotropic glutamate receptors inhibits glutamatergic transmission in the rat entorhinal cortex via reduction of glutamate release probability. Cereb Cortex 22:584-594. CrossRef Medline

Wang S, Kurada L, Cilz NI, Chen X, Xiao Z, Dong H, Lei S (2013) Adenosinergic depression of glutamatergic transmission in the entorhinal cortex of juvenile rats via reduction of glutamate release probability and the number of releasable vesicles. PLoS One 8:e62185. CrossRef Medline

Watanabe M, Nakamura M, Sato K, Kano M, Simon MI, Inoue Y (1998) Patterns of expression for the mRNA corresponding to the four isoforms of phospholipase Cbeta in mouse brain. Eur J Neurosci 10:2016-2025. CrossRef Medline

Wolf SS, Hyde TM, Moody TW, Saunders RC, Weinberger DR, Kleinman JE (1994) Autoradiographic characterization of ${ }^{125}$ I-neurotensin binding sites in human entorhinal cortex. Brain Res Bull 35:353-358. CrossRef Medline

Wolf SS, Hyde TM, Saunders RC, Herman MM, Weinberger DR, Kleinman JE (1995) Autoradiographic characterization of neurotensin receptors in the entorhinal cortex of schizophrenic patients and control subjects. J Neural Transm Gen Sect 102:55-65. CrossRef Medline

Xiao Z, Deng PY, Rojanathammanee L, Yang C, Grisanti L, Permpoonputtana K, Weinshenker D, Doze VA, Porter JE, Lei S (2009) Noradrenergic depression of neuronal excitability in the entorhinal cortex via activation of TREK-2 $\mathrm{K}^{+}$channels. J Biol Chem 284:10980-10991. CrossRef Medline

Yagi K, Goto D, Hamamoto T, Takenoshita S, Kato M, Miyazono K (1999) Alternatively spliced variant of Smad2 lacking exon 3: comparison with wild-type Smad2 and Smad3. J Biol Chem 274:703-709. CrossRef Medline

Yamauchi R, Wada E, Kamichi S, Yamada D, Maeno H, Delawary M, Nakazawa T, Yamamoto T, Wada K (2007) Neurotensin type 2 receptor is involved in fear memory in mice. J Neurochem 102:1669-1676. CrossRef Medline

Yin HH, Adermark L, Lovinger DM (2008) Neurotensin reduces glutamatergic transmission in the dorsolateral striatum via retrograde endocannabinoid signaling. Neuropharmacology 54:79-86. CrossRef Medline

Zhang HP, Xiao Z, Cilz NI, Hu B, Dong H, Lei S (2014) Bombesin facilitates GABAergic transmission and depresses epileptiform activity in the entorhinal cortex. Hippocampus 24:21-31. CrossRef Medline 